\title{
Air-Injection Testing in Vertical Boreholes in Welded and Nonwelded Tuff, Yucca Mountain, Nevada
}

by Gary D. LeCain

\section{U.S. GEOLOGICAL SURVEY}

Water-Resources Investigations Report 96-4262

Prepared in cooperation with the

NEVADA OPERATIONS OFFICE,

U.S. DEPARTMENT OF ENERGY, under

Interagency Agreement DE-Al08-92NV10874 


\title{
U.S. DEPARTMENT OF THE INTERIOR \\ BRUCE BABBITT, Secretary
}

\author{
U.S. GEOLOGICAL SURVEY \\ Gordon P. Eaton, Director
}

The use of firm, trade, and brand names in this report is for identification purposes only and does not constitute endorsement by the U.S. Geological Survey.

For additional information write to:

Chief, Earth Science Investigations Program Yucca Mountain Project Branch

U.S. Geological Survey

Box 25046, Mail Stop 421

Denver Federal Center

Denver, CO 80225-0046
Copies of this report can be purchased from:

U.S. Geological Survey

Branch of Information Services

Box 25286

Denver, CO 80225-0286 


\section{CONTENTS}

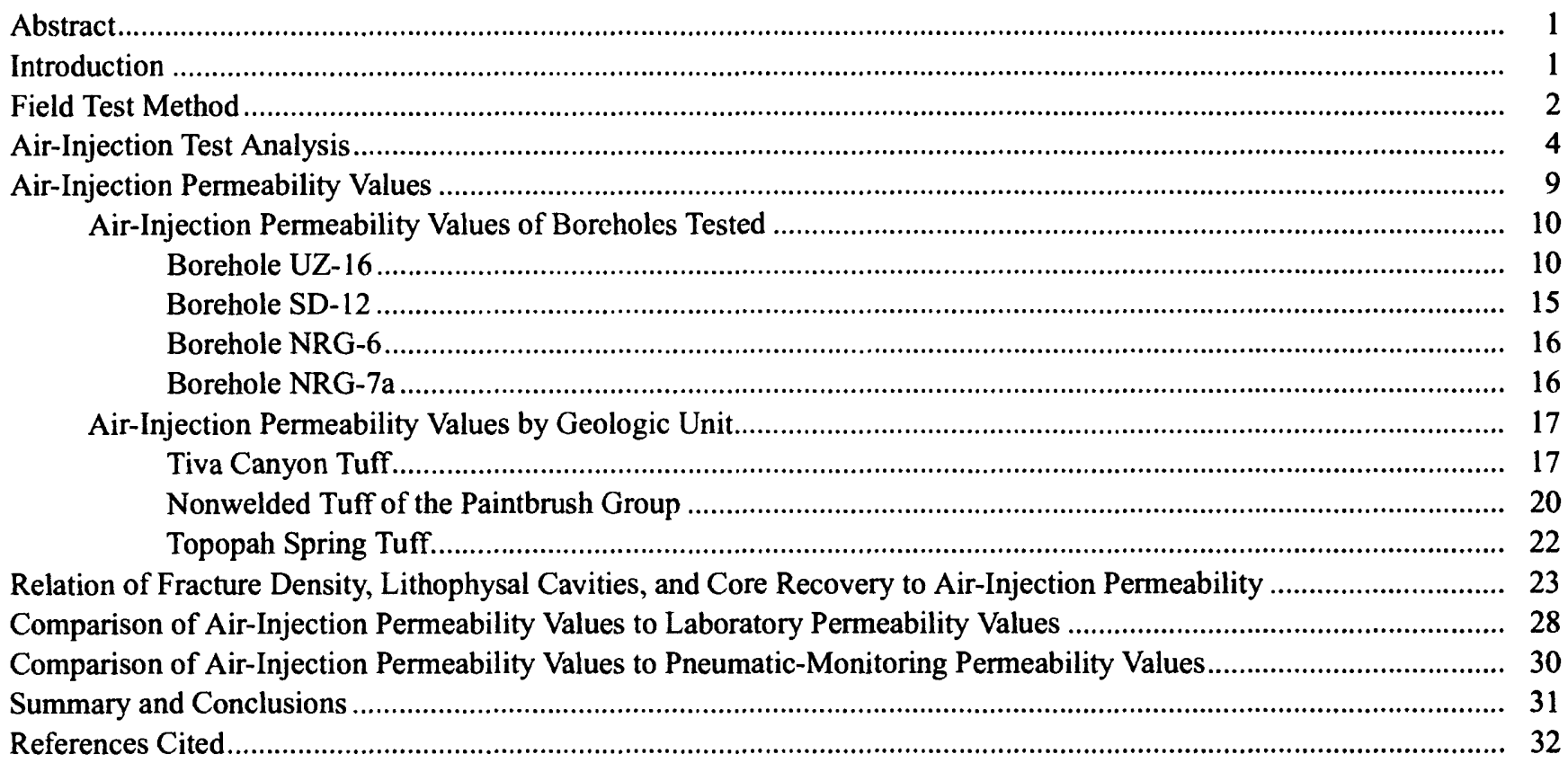

\section{FIGURES}

1. Maps showing the Yucca Mountain area, potential repository boundary, and borehole locations........................... 3



3-11. Graphs showing:

3. Absolute pressure as a function of time in the test and guard intervals during air-injection test 68 , borehole NRG-7a

4. Differential pressures as a function of time in the test interval during air-injection test 68 , borehole NRG-7a

5. Steady-state differential pressures squared as a function of flow rates of tests 37,38 , and 39 , borehole NRG-7a

6. Differential pressures squared as a function of time in the test interval during recovery tests 36 and 37 , borehole SD-12

7. Relation of air-injection permeability values to depth and geologic zone penetrated in borehole UZ-16

8. Relation of air-injection permeability values to depth and geologic zone penetrated in borehole SD-12

9. Relation of air-injection permeability values to depth and geologic zone penetrated in borehole NRG-6.

10. Relation of air-injection permeability values to depth and geologic zone penetrated in borehole NRG-7a

11. Absolute pressure as a function of time in the test interval during air-injection test 17 , borehole UZ-16

12. Histograms showing air-injection permeability values and basic statistics of the Tiva Canyon Tuff by borehole

13. Histograms showing natural log air-injection permeability values and basic statistics of the Tiva Canyon Tuff by borehole.

14. Graph showing air-injection permeability values of the nonwelded tuff of the Paintbrush Group with depth, borehole NRG-7a 
15-18. Histograms showing:

15. Air-injection permeability values of the nonwelded tuff of the Paintbrush Group, borehole NRG-7a.

16. Natural log air-injection permeability values of the nonwelded tuff of the Paintbrush Group, borehole NRG-7a.

17. Air-injection permeability values and basic statistics of the Topopah Spring Tuff by borehole

18. Natural log air-injection permeability values and basic statistics of the Topopah Spring Tuff by borehole.

19. Variograms showing natural log air-injection permeability values of the Topopah Spring Tuff by borehole

20. Graph showing relation of air-injection permeability values and number of natural fractures, borchole NRG-6.

21. Graph showing relation of air-injection permeability values and number of natural fractures, borehole NRG-7a.

\section{TABLES}

1. Statistical summary of Tiva Canyon Tuff air-injection permeability values by borehole

2. Statistical summary of Tiva Canyon Tuff air-injection permeability values by geologic zone and borehole

3. Statistical summary of the air-injection permeability values of the nonwelded tuff of the Paintbrush Group

4. Statistical summary of the air-injection permeability values of the nonwelded tuff of the Paintbrush Group by geologic zone.

5. Statistical summary of Topopah Spring Tuff air-injection permeability values by borehole

6. Statistical summary of Topopah Spring Tuff air-injection permeability values by geologic zone and borehole

7. Average number of natural fractures per test interval by geologic unit and borehole

8. Goodness-of-fit values from univariate regression analysis between air-injection permeability values and six explanatory variables

9. Pneumatic-monitoring permeability values and air-injection permeability values from boreholes NRG-6 and NRG-7a by geologic unit 
CONVERSION FACTORS AND VERTICAL DATUM

\begin{tabular}{rll}
\hline Multiply & By & To obtain \\
\hline centimeter $(\mathrm{cm})$ & 0.3937 & inch \\
cubic meter per second $\left(\mathrm{m}^{3} / \mathrm{s}\right)$ & $15,852.0$ & gallon per minute \\
kilogram $(\mathrm{kg})$ & 2.205 & pound avoirdupois \\
kilogram per cubic meter $\left(\mathrm{kg} / \mathrm{m}^{3}\right)$ & 0.062 & pound per cubic foot \\
kilometer $(\mathrm{km})$ & 0.6214 & mile \\
kilopascal $(\mathrm{kPa})$ & 0.145 & pound-force per square inch \\
meter $(\mathrm{m})$ & 3.281 & foot \\
meter per second $(\mathrm{m} / \mathrm{s})$ & 196.850 & foot per minute \\
metric ton & 0.892 & ton (short) \\
millimeter & 0.0394 & inch \\
square meter $\left(\mathrm{m}^{2}\right)$ & 10.765 & square foot \\
Pascal $(\mathrm{Pa})$ & $1.45 \times 10^{-4}$ & pound-force per square inch \\
Pascal second $\left(\mathrm{Pa}^{*} \mathrm{~s}\right)$ & 10.0 & poise \\
standard liter per minute $(\mathrm{slpm})$ & 0.2642 & gallons per minute
\end{tabular}

*In this report, the term standard means a measurement taken at a temperature of 0 degree Celsius and atmospheric pressure of 101.3 kiloPascals.

Temperature in degrees Celsius $\left({ }^{\circ} \mathrm{C}\right)$ may be converted to degrees Fahrenheit $\left({ }^{\circ} \mathrm{F}\right)$ as follows:

$$
{ }^{\circ} \mathrm{F}=\left(1.8 \times{ }^{\circ} \mathrm{C}\right)+32
$$

The permeability equations use degree Kelvin. To convert degree Kelvin $\left({ }^{\circ} \mathrm{K}\right)$ to degree Fahrenheit $\left({ }^{\circ} \mathrm{F}\right)$ use the following formula:

$$
{ }^{\circ} \mathrm{F}=9 / 5\left({ }^{\circ} \mathrm{K}\right)-459.67
$$

Sea level: In this report, "sea level" refers to the National Geodetic Vertical Datum of 1929 (NGVD of 1929)-a geodetic datum derived from a general adjustment of the first-order level nets of both the United States and Canada, formerly called Sea Level Datum of 1929. 


\title{
Air-Injection Testing in Vertical Boreholes in Welded and Nonwelded Tuff, Yucca Mountain, Nevada
}

\author{
By Gary D. LeCain
}

\section{Abstract}

Air-injection tests, by use of straddle packers, were done in four vertical boreholes (UE-25 UZ-\#16, USW SD-12, USW NRG-6, and USW NRG-7a) at Yucca Mountain, Nevada. The geologic units tested were the Tiva Canyon Tuff, nonwelded tuffs of the Paintbrush Group, Topopah Spring Tuff, and Calico Hills Formation. Air-injection permeability values of the Tiva Canyon Tuff ranged from $0.3 \times 10^{-12}$ to $54.0 \times$ $10^{-12} \mathrm{~m}^{2}$ (square meter). Air-injection permeability values of the Paintbrush nonwelded tuff ranged from $0.12 \times 10^{-12}$ to $3.0 \times 10^{-12} \mathrm{~m}^{2}$. Airinjection permeability values of the Topopah Spring Tuff ranged from $0.02 \times 10^{-12}$ to $33.0 \times$ $10^{-12} \mathrm{~m}^{2}$. The air-injection permeability value of the only Calico Hills Formation interval tested was $0.025 \times 10^{-12} \mathrm{~m}^{2}$. The shallow test intervals of the Tiva Canyon Tuff had the highest airinjection permeability values.

Variograms of the air-injection permeability values of the Topopah Spring Tuff show a hole effect; an initial increase in the variogram values is followed by a decrease. The hole effect is due to the decrease in permeability with depth identified in several geologic zones. The hole effect indicates some structural control of the permeability distribution, possibly associated with the deposition and cooling of the tuff.

Analysis of variance indicates that the airinjection permeability values of borehole NRG-7a of the Topopah Spring Tuff are different from the other boreholes; this indicates areal variation in permeability.
Air-injection redistribution of water was identified in the Calico Hills Formation and the Tiva Canyon Tuff. The tests indicate that water had flowed in the fractures of the Tiva Canyon Tuff at the time of the tests.

The air-injection permeability values of the welded tuffs of the Tiva Canyon Tuff and the Topopah Spring Tuff are three to six orders of magnitude greater than the permeability values of the laboratory-welded tuff matrix. The higher airinjection permeability values are due to fracture flow. The air-injection permeability values of the Paintbrush nonwelded tuff are generally higher than laboratory matrix permeability values; this indicates that there are open fractures in the Paintbrush nonwelded tuff.

The pneumatic-monitoring permeability values of the Tiva Canyon Tuff and the Paintbrush nonwelded tuff agree with the air-injection permeability values. The pneumatic-monitoring permeability values of the Topopah Spring Tuff are an order of magnitude larger than the airinjection permeability values; this indicates that the Topopah Spring Tuff is anisotropic with a vertical to horizontal permeability ratio of about 10:1.

\section{INTRODUCTION}

The Yucca Mountain Project is a U.S. Department of Energy (DOE) scientific study to evaluate the potential for geologic disposal of high-level radioactive waste in an unsaturated zone desert environment. The potential repository site at Yucca Mountain is 
located approximately $130 \mathrm{~km}$ northwest of Las Vegas, Nevada, at the DOE Nevada Test Site. The U.S. Geological Survey (USGS) is conducting geologic and hydrologic studies of the potential repository site for DOE. The purpose of these studies is to quantify the geologic and hydrologic characteristics of Yucca Mountain and surrounding areas to conceptualize and model gas and liquid flow at the potential repository site.

Air-injection tests were done in vertical boreholes at Yucca Mountain to quantify the in-situ air permeability of the unsaturated fractured and unfractured volcanic rocks (tuff). The permeability of these tuffs control the movement of fluids in Yucca Mountain. Potential fluid movement in Yucca Mountain includes the transmission of water from the surface downward to the repository horizon and the movement of gases from the repository horizon to the surface. Variations in the tuff permeability can result in perched water zones, fast pathways, and capillary barriers. These variations may occur between stratigraphic units or within individual stratigraphic units. Knowledge of the spatial and directional variability of permeability is needed to formulate conceptual models and is required input to flow and transport models that attempt to represent the flow system at Yucca Mountain.

This report presents the air-permeability values from 194 single-hole air-injection tests conducted in 4 vertical boreholes at Yucca Mountain at the Nevada Test Site. Figure 1 shows the location of Yucca Mountain, the potential repository site, and the four boreholes. From 1993 through 1995, boreholes UZ-16 (unsaturated \#16), SD-12 (systematic drilling \#12), NRG-6 (north ramp geology \#6), and NRG-7a (north ramp geology \#7a) were tested using a straddle-packer air-injection system. The geologic units tested were the Tiva Canyon, Yucca Mountain, Pah Canyon, Topopah Spring, Calico Hills, and three bedded tuff units. This report presents the calculated air-injection permeability values by borehole and by geologic unit. Comparisons of the air-injection permeability values to permeability values derived from laboratory tests and pneumatic monitoring are included. Regression analysis between air-injection permeability values and rock characteristics (fracture density and lithophysal cavities) is presented. Also included are the field test method, the data analysis method, and a brief discussion of the potential effects of turbulence, Klinkenberg effect, and water redistribution.

\section{FIELD TEST METHOD}

The surface air-permeability testing program at Yucca Mountain consisted of air-injection tests conducted in the unsaturated zone. The equipment was state-of-the-art hydraulic, pneumatic, and electrical systems that allow the installation of pneumatic packers in vertical boreholes. Tests began with a review of the borehole geophysical logs (caliper, natural gamma, and gamma-gamma) and selection of the downhole test intervals. After a test interval was selected, the pneumatic packers were installed in the vertical borehole, lowered to the selected test interval, and inflated with compressed air. Inflation of the packers isolated the selected test interval from the open borehole. After packer inflation, the compressed air, tagged with sulfur hexafluoride tracer gas, was injected into the isolated test interval at a constant rate until the pressure in the test interval stabilized. An average test lasted approximately 10 minutes. Tests conducted in borehole SD-12 (systematic drilling \#12) were followed by recovery tests.

Figure 2 is a schematic of the air-injection testing field system. The downhole test equipment consisted of four pneumatic packers connected endto-end by aluminum pipe, which forms a packer assembly with three intervals. The middle interval is the test interval, and the two end intervals are guard intervals. The test interval length ranged from 3.5 to $4.9 \mathrm{~m}$. The length of the guard intervals was $1.2 \mathrm{~m}$. In boreholes that required a longer test interval, because of poor wall conditions or other problems with the packers, only the outside packers were inflated. When only the outside packers were inflated, the test interval length was $11.3 \mathrm{~m}$. Each of the intervals contained a pressure transducer (to measure absolute pressure) and a thermistor (to measure temperature). The downhole packer assembly was connected to the surface by a 700 -m-long tubing bundle. The tubing bundle contained: (1) four 3/8-in.-diameter electrical cables to power and monitor the pressure transducers and thermistors; (2) two 3/8-in.-diameter nylon tubes to inflate the packers; (3) one 1-in.-diameter tube for airinjection; and (4) a 3/8-in.-diameter steel cable to support the weight of the packers and tubing bundle. The packer assembly was lowered and raised in the borehole with a surface-mounted hydraulic winch. The instruments were powered and monitored and the data recorded by data loggers at the surface. When a test interval was selected, the packer assembly was 



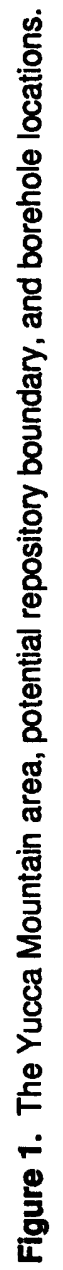




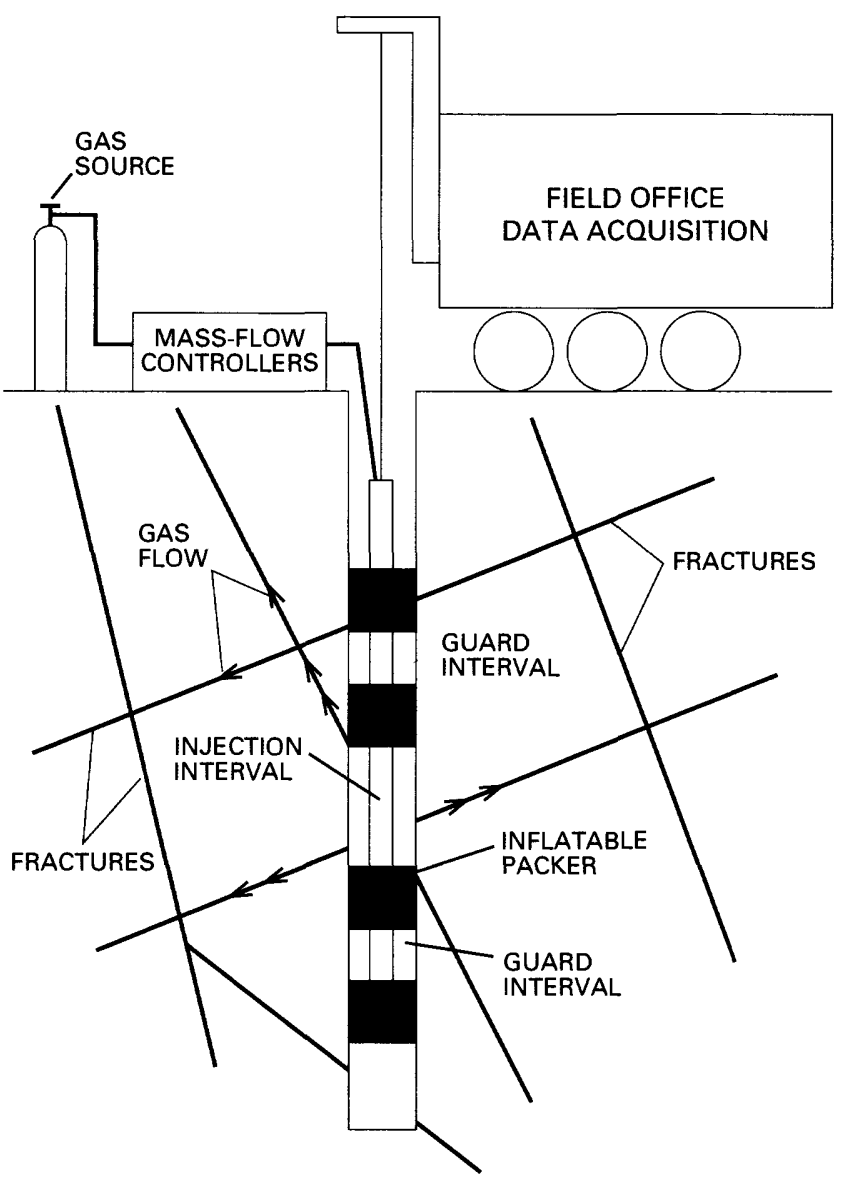

Figure 2. An air-injection testing field system.

lowered to the selected interval and all four packers were inflated. Once the packers were inflated, massflow controllers were used to inject a constant mass flow of compressed air with a sulfur hexafluoride tracer. The mass flow rate ranged from 1.0 to $1,500.0$ standard liters per minute (slpm). The air flow into the test interval resulted in an increase in pressure and a change in temperature. The electrical outputs of the pressure transducers and thermistors were converted into engineering units of pressure and temperature. The test-interval pressure and temperature responses were used to calculate an air-injection permeability value for the test interval. The purpose of the guard intervals was to monitor for injection-air leakage around the inner two packers, which would invalidate the test.

\section{AIR-INJECTION TEST ANALYSIS}

The method used to analyze the air-injection tests was originally developed for incompressible fluids. Modifications for compressible fluids and flow geometry require the following assumptions.

1. The ideal gas law applies, and therefore, the compressibility of the gas is inversely related to the pressure.

$$
C=\frac{1}{P}
$$

where,

$c=$ compressibility, in Pascals ${ }^{-1}$;

$P=$ pressure, in Pascals.

2. The system is isothermal, and therefore, the gas density and viscosity, which are both temperature dependent, remain constant. The effect of temperature change on the gas density can be evaluated by equation 2 (Weast, 1987),

$$
\rho=\rho_{s c}\left(\frac{T s c}{T}\right)
$$

where,

$\rho=$ gas density, in kilograms per cubic meter;

$\rho_{s c}=$ gas density at standard conditions, in kilograms per cubic meter;

$T_{s c}=$ temperature at standard conditions, in Kelvin; and

$T$ = temperature, in Kelvin.

An approximate effect of temperature change on gas viscosity can be evaluated by equation 3 (Noggle, 1985),

$$
\mu=\mu_{s c} \sqrt{\frac{T}{T_{s c}}}
$$

where,

$\mu=$ dynamic viscosity, in Pascal seconds; and

$\mu_{s c}=$ dynamic viscosity at standard conditions, in Pascal seconds. 
3. Gravitational effects can be excluded, which is reasonable because the increased pressure from the weight of the higher density gas is small compared to the gas-injection pressure.

4. Flow is laminar. Calculation of air-injection permeability values assumes that the flux of a gas through a medium is proportional to the differential pressure across which the flow occurs, which is true as long as Darcy's Law is valid. Darcy's Law may be invalidated by turbulent flow in fractures and inertial or Klinkenberg effects in the matrix. Nonlaminar flow could result in the calculated permeability values being dependent on the flux and, therefore, on the gas-injection rate.

Turbulence, inertial, and Klinkenberg effects were evaluated by steady-state tests at multiple gasinjection rates. An arithmetic plot of the steady-state $\Delta \mathrm{P}^{2}$ (differential pressure squared) and the gasinjection rate was prepared. If the plot was a straight line through the origin then the flow was Darcian; if not, the permeability determination may not be independent of the flux. Dullien (1992) provides a method to deal with inertial nonlinearity. The method might also be applied to turbulent flow in fractured media. The method requires multiple tests at increasing gas-injection rates and use of the Forchheimer method (Norman and Archer, 1988) to estimate the inertial coefficient and ultimately the Darcian flow permeability; the method would require a minimum of five tests per test interval. Air-injection tests conducted by LeCain (1995) in moderately welded tuff near Superior, Arizona, indicated that if the differential pressure was limited to a maximum of $160 \mathrm{kPa}$, gas-injection tests in both fractured and nonfractured intervals had no decrease in permeability with increased flow rates. On the other hand, tests conducted by Sully (M.J. Sully, REECO, written commun., 1996) in desert alluvium at the Nevada Test Site indicate that in some test intervals, inertial effects could be seen when differential pressures were as small as $10 \mathrm{kPa}$.

The Klinkenberg effect (Klinkenberg, 1941) is a concern only in matrix flow where permeability values are less than $10^{-14} \mathrm{~m}^{2}$ (Weeks, 1978). The Klinkenberg effect states that in fine-grained materials at low pressures, slippage of molecules occurs. The effect is the opposite of turbulence or inertial influences; the lower injection-rate tests produce higher permeability values than the higher flow-rate tests. The slippage is expressed mathematically as,

$$
k=k_{h}\left(1+\frac{b}{P}\right)
$$

where,

$k=$ effective permeability, in square meters;

$k_{h}=$ high pressure permeability, in square meters; and

$b=$ Klinkenberg parameter, in Pascals.

Because field testing time was limited, the intention was to minimize the number of repetitive tests and maximize the number of test intervals. Injection rates were limited in order to minimize turbulent and inertial flow influences. The differential injection pressures were restricted to $30 \mathrm{kPa}$, and three tests at increasing flow rates were conducted on each test interval. An arithmetic plot of the three steadystate $\Delta \mathrm{P}^{2}$ values and flow rates was prepared and examined for linearity. If, in the opinion of the operator, the plot was reasonably linear, testing was halted and the packer assembly moved to the next test interval. If the plot was nonlinear, one or more additional tests were conducted at lower injection rates.

5. The medium is homogeneous, isotropic, and incompressible. The homogeneous and isotropic assumptions are questionable in most test situations and are even more suspect when tests are performed in fractured rock. Fractures, by their nature, are not isotropic, and the presence of fractures in a low-permeability matrix means the rock is not homogeneous. The rationale for these assumptions considers the scale of the tests and the REV (representative elementary volume). In the simplest terms, the REV is the minimum sample size at which the rock behaves as an equivalent porous medium. In a fractured system, this means the test interval must intercept enough fractures so that the flow system behaves as an equivalent porous medium. Based on the structural and core log fracture data, a test interval length of $4.0 \mathrm{~m}$ was selected. The actual test-interval lengths ranged from 3.5 to $4.6 \mathrm{~m}$. The lengths had to be modified because the different borehole diameters necessitated modifications to the packer assembly. Tests conducted 
in a fractured medium at a scale smaller than the REV will mean the flow geometry is inconsistent and unknown. Tests conducted at a scale larger than the REV may result in the loss of information on the variability that exists in even the most consistent rock formations.

Because the air permeability of a rock changes with water content, a given permeability also has an associated capillary pressure. Capillary pressure is the pressure difference across the interface between the gas and liquid phases. Capillary pressure increases when this interface is confined to smaller pores or smaller fractures and decreases as this interface moves to larger pores or larger fractures. The larger pores and fractures are potentially the most conductive features and are dry at all but the wettest conditions (lowest capillary pressures). By use of the capillary equations (Bikerman, 1958),

$$
\begin{aligned}
& P=\frac{2 \gamma}{r} \\
& P=\frac{2 \gamma}{a}
\end{aligned}
$$

where,

$$
\begin{aligned}
& P=\text { pressure, in Pascals; } \\
& \gamma=\text { surface tension of water, in Pascal meters; } \\
& r=\text { pore radius, in meters; and } \\
& a=\text { fracture aperture, in meters. }
\end{aligned}
$$

it is possible to approximate the size of the pores and fractures that will be dry at a given capillary pressure. For example, if the steady-state test differential pressure is $30.0 \mathrm{kPa}$, the associated pore radius and fracture aperture is $4.8 \mu \mathrm{m}$ (micrometers). Therefore, at $30.0 \mathrm{kPa}$, pores with a radius and fractures with an aperture larger than $4.8 \mu \mathrm{m}$, lack the capillary force to retain water, and the water will be forced out of these pores and fractures.

Steady-state analysis was used to evaluate the test-interval pressure response. The analysis uses a modified version of the Hvorslev (1951) solution for steady-state elliptical flow. The air-injection tests used a packer string with a test interval length of approximately $4 \mathrm{~m}$. Based on the assumption that the rock is isotropic and the flow geometry is elliptical, the zone of investigation is an ellipsoid that extends approxi- mately $4 \mathrm{~m}$ in all directions from the test interval. Analysis is based on the assumption that the pressure in the injection interval is at steady state. The solution is modified for compressible fluids. The original equation is expressed as,

$$
K=\frac{Q \ln \left(\frac{L}{2 r_{w}}+\sqrt{1+\left(\frac{L}{2 r_{w}}\right)^{2}}\right)}{2 \pi \Delta H L}
$$

where,

$K=$ hydraulic conductivity, in meters per second;

$Q=$ flow rate, in cubic meters per second;

$L=$ length, in meters;

$r_{\mathrm{w}}=$ well radius, in meters; and

$\Delta H=$ change in head, in meters.

The change in head and hydraulic conductivity can be redefined as,

$$
\Delta H=\frac{P_{2}-P_{1}}{\rho g}
$$

$$
K=\frac{k \rho g}{\mu}
$$

where,

$$
\begin{aligned}
P_{2}= & \text { final pressure, in Pascal; } \\
P_{1}= & \text { starting pressure, in Pascal; } \\
g & =\text { acceleration of gravity, in meters per second } \\
& \text { squared; and } \\
k= & \text { permeability, in meter squared. }
\end{aligned}
$$

Volumetric flux in the formation can be expressed as,

$$
Q=\frac{2 \pi L\left(P_{2}-P_{1}\right) k}{\mu \ln \left(\frac{L}{2 r_{w}}+\sqrt{1+\left(\frac{L}{2 r_{w}}\right)^{2}}\right)}
$$

The pneumatic testing program uses mass flow controllers to control the mass flow rate. Because mass flux is constant,

$$
\rho_{h} Q_{h}=\rho_{f} Q_{f}=\rho_{s c} Q_{s c}
$$


where the subscripts are,

${ }_{h}=$ in the injection hose;

$f=$ in the formation; and

$s_{c}=$ at standard conditions.

Pressure and temperature for an ideal gas are related by,

$$
\rho=\frac{P}{R_{g} T}
$$

where,

$$
\begin{gathered}
R_{g}=\text { individual gas constant, in joules per } \\
\text { kilogram Kelvin. }
\end{gathered}
$$

therefore, if the temperature is constant,

$$
p_{h} Q_{h}=p_{f} Q_{f}=p_{s c} Q_{s c}
$$

Based on the assumption that the average formation pressure is,

$$
P_{f}=\frac{\left(P_{2}+P_{1}\right)}{2}
$$

and the average flow volume in the formation is given by equation 10 , then equations 10,13 , and 14 can be combined to yield

$$
\begin{aligned}
& P_{f} Q_{f}=P_{s c} Q_{s c}= \\
& \frac{P_{2}+P_{1}}{2} \frac{2 \pi L\left(P_{2}-P_{1}\right) k}{\mu \ln \left(\frac{L}{2 r_{w}}+\sqrt{1+\left(\frac{L}{2 r_{w}}\right)^{2}}\right)}
\end{aligned}
$$

and the temperature correction yields,

$$
k=\frac{P_{s c} Q_{s c} \mu \ln \left(\frac{L}{2 r_{w}}+\sqrt{1+\left(\frac{L}{2 r_{w}}\right)^{2}}\right) T_{f}}{\pi L\left(P_{2}^{2}-P_{1}^{2}\right) T_{s c}}
$$

Figure 3 is a plot of the pressure responses with time in the test and guard intervals during test 68 , borehole NRG-7a. Test 68 was done at the repository level in the crystal-poor middle nonlithophysal zone of the Topopah Spring Tuff. This pressure response is typical of the tests on welded and fractured tuff. The test-interval pressure begins to rise approximately 3 seconds after air injection begins. The 3 -second delay is due to the compressibility of the injection gas and the $700-\mathrm{m}$ length of the air-injection tube. The test-interval pressure increases for approximately 300 seconds and reaches steady-state pressure at $96.5 \mathrm{kPa}$. The short time period required to reach steady state agrees with Kearl and others (1990) whose air-injection testing in the Bandelier Tuff near Los Alamos, New Mexico, indicated that "steady-state conditions were generally obtained a few minutes after the air injection was initiated." The guard-intervals pressure responses lag the test interval by approximately 10 seconds and reach steady state at significantly lower pressures, 89.95 and $89.98 \mathrm{kPa}$. The time lag and lower steady-state pressures indicate that the packers have seated properly and the test is acceptable. The absence of a time lag or a pressure response in a guard interval similar to the pressure response in the test interval indicates that the packers have not isolated the test interval and the test is void. Tests conducted on the bedded tuffs show similar pressure responses, except that the guard-interval time lags are longer, approximately 3 minutes. The longer time lag is due to the higher porosity of the bedded tuffs. Most of the pressure plots have similar shapes. This indicates that the flow geometry was stable and that the test interval length satisfied the REV assumptions.

Figure 4 is a log-log plot of the differential pressure with time in the test interval during test 68 , borehole NRG-7a. The log-log plot is used to identify periods when gas flow was not constant. The compressibility of the injection gas and length of the injection-gas tube can cause problems with maintaining a constant flow rate in the early time period of a test. Based on the assumption that the injection gas (compressed air) behaves as an ideal gas, the slope of a $\log -\log$ plot of differential pressure with time would not exceed one. A slope greater than one indicates an increasing mass flow rate, with time, in the test interval. A slope equal to one indicates that all the injected gas has gone into wellbore storage.

Figure 4 indicates that during the first approximately 25 seconds of test 68 , the flow rate was not constant, 


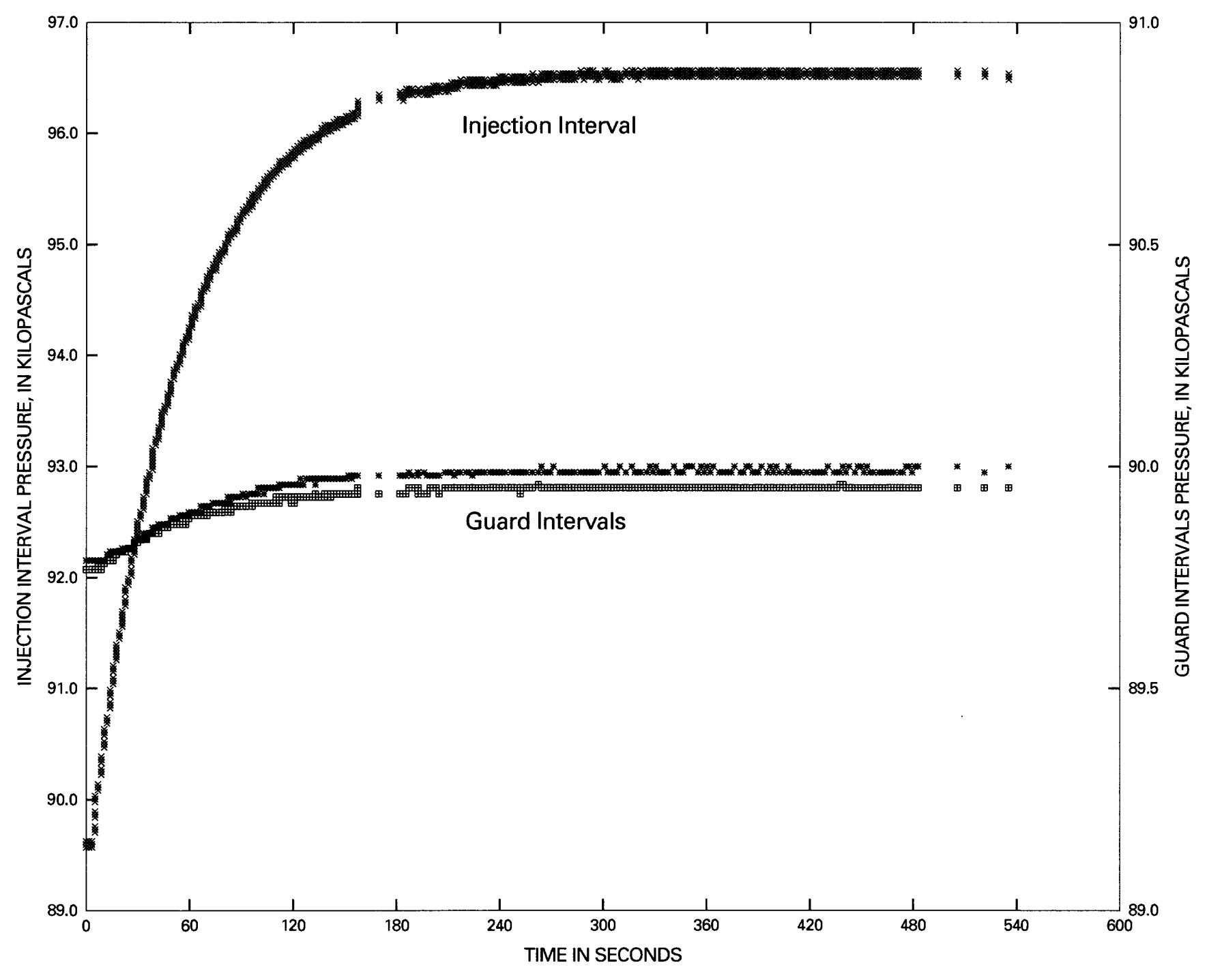

Figure 3. Absolute pressure as a function of time in the test and guard intervals during air-injection test 68 , borehole NRG-7a. 
which is due to the 700-m length of the gas-injection tube. Because the early-time increasing flow-rate period is short, in relation to the time allocated for the tests to reach steady state, the increasing flow rate did not affect the calculated permeability values.

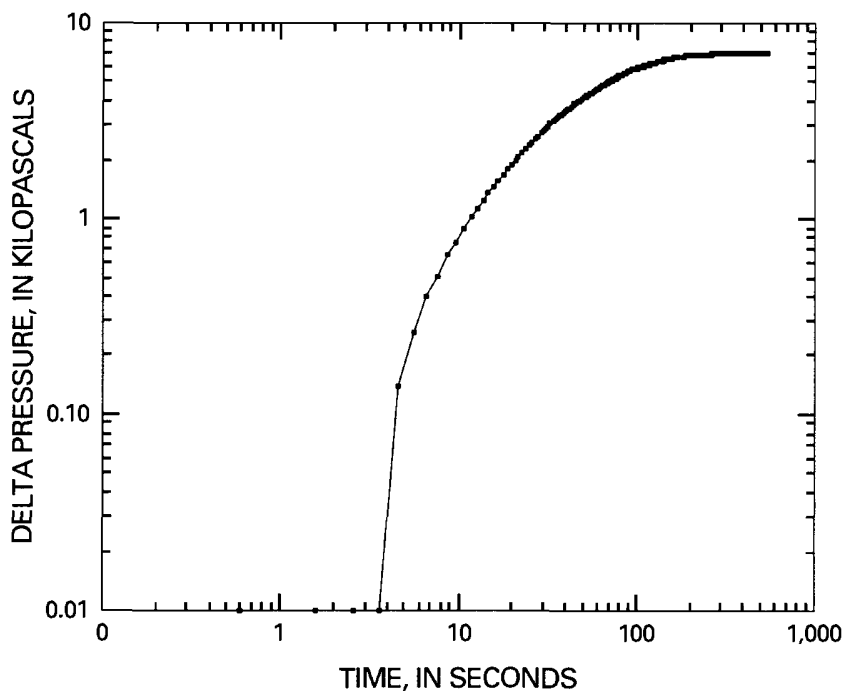

Figure 4. Diifferential pressures as a function of time in the test interval during air-injection test 68 , borehole NRG-7a.

Figure 5 is a plot of the steady-state differential pressures squared with the flow rates of tests 37,38 , and 39, borehole NRG-7a. The tests were done on the same test interval in the crystal-poor upper lithophysal zone of the Topopah Spring Tuff at flow rates of 30 , 60 , and 90 slpm. The plot is linear and passes through the origin; this indicates that the flow is darcian. Some test intervals indicated turbulence as a decrease in permeability with increasing flow rates. These effects were minimized by limiting the steady-state injection pressures, with a few exceptions, to a maximum of $30 \mathrm{kPa}$. A total of 194 test intervals were tested in the 4 boreholes; 181 had multiple tests at different flow rates. Of these, 93 had a minimum permeability value within 12 percent of their maximum permeability value, and 170 had a minimum permeability value within 30 percent of their maximum permeability value. These ranges compare well with tests to evaluate the range of permeability values calculated when all variables are held constant. Tests conducted in borehole SD-12 included five 301-slpm air-

injection tests performed on a single test interval. The permeability values were $1.6,1.6,1.7,1.7$, and $1.5 \times$ $10^{-12} \mathrm{~m}^{2}$, a range of 12 percent.

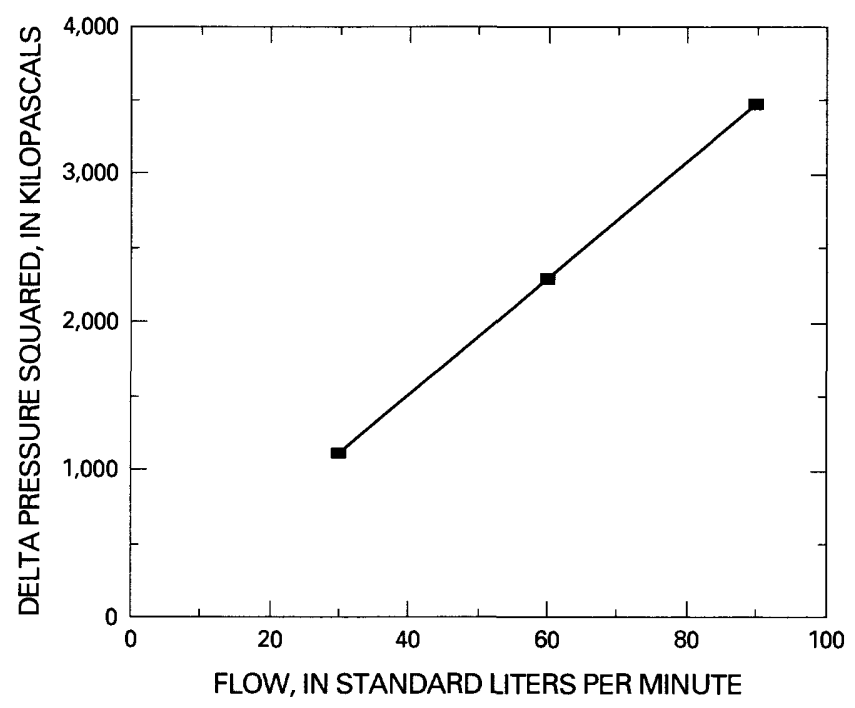

Figure 5. Steady-state differential pressures squared as a function of flow rates of tests 37,38 , and 39 , borehole NRG-7a.

Figure 6 presents a plot of the differential pressures squared with time during recovery tests 36 and 37 , borehole SD-12. The two recovery tests followed air-injection tests 36 and 37 . Air-injection tests 36 and 37 were done on the same test interval at similar air-injection rates (approximately 300 slpm). Air-injection test 36 lasted 15 minutes, and airinjection test 37 lasted 16.7 hours. Both recovery tests were completely recovered in less than 100 seconds. The difference in the test pressures is due to the limited accuracy of the mass-flow controllers. The recovery response indicates that both injection tests had reached steady-state flow in less than 15 minutes, and therefore, test periods longer than 15 minutes were unnecessary.

\section{AIR-INJECTION PERMEABILITY VALUES}

Figures 7 through 10 present the air-injection permeability values, with depth, of the test intervals in boreholes UZ-16, SD-12, NRG-6, and NRG-7a. Also included are the geologic members and zones (Geslin and others, 1995). The permeability values assigned to each test interval in figures 7 through 10 are from the test that had the smallest steady-state differential pressures. These permeability values had the smallest probability of turbulence or inertial affects. These assigned permeability values were used to prepare the figures, tables, and statistical analysis presented in this section of this report. 


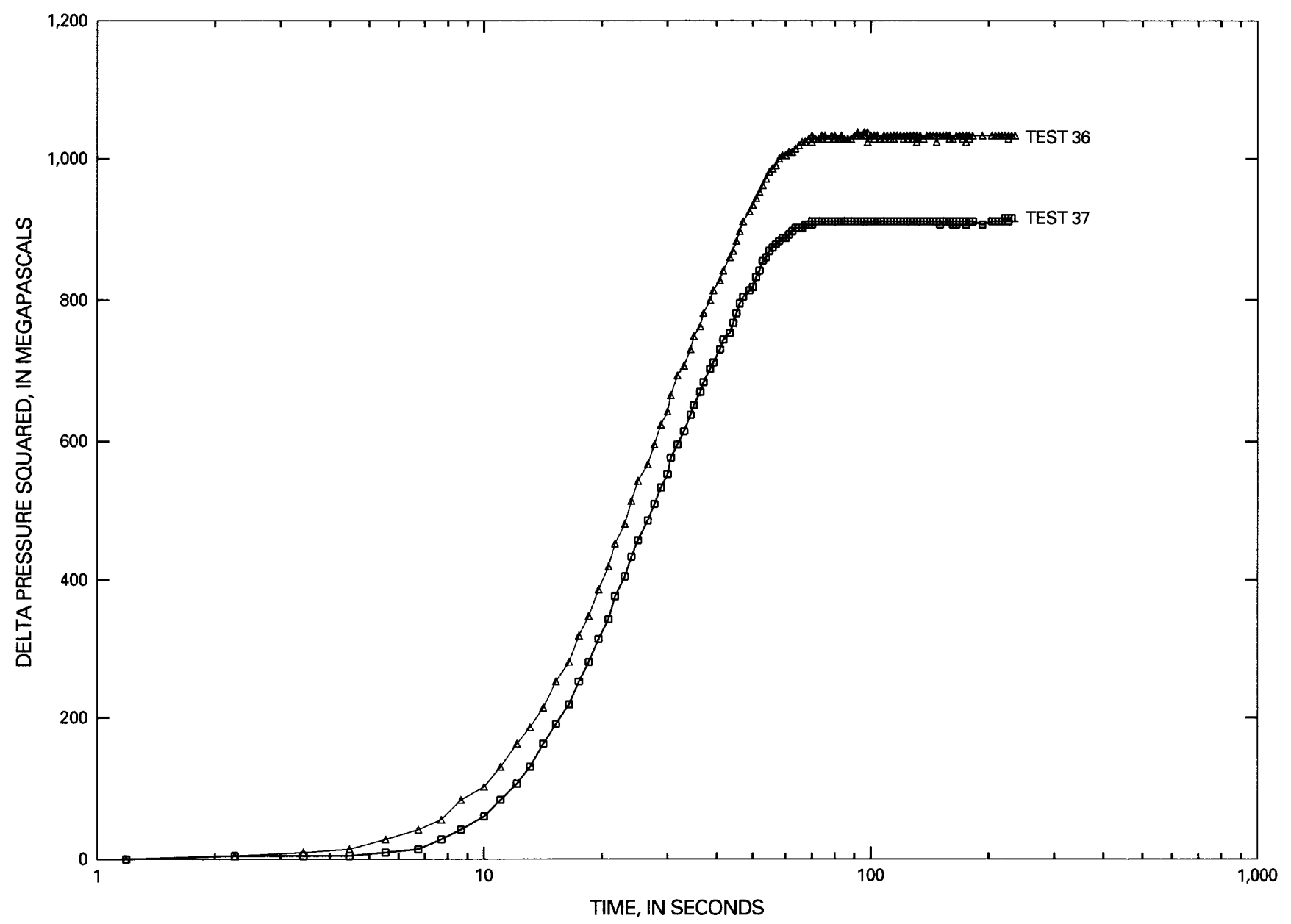

Figure 6. Differential pressures squared as a function of time in the test interval during recovery tests $\mathbf{3 6}$ and $\mathbf{3 7 .}$ borehole SD-12.

\section{Air-Injection Permeability Values of Boreholes Tested}

\section{Borehole UZ-16}

Borehole UZ-16 was the first to be tested (November 1993 through May 1994). The borehole diameter was $0.31 \mathrm{~m}$ and total depth was $514.1 \mathrm{~m}$. The test-interval length was $4.0 \mathrm{~m}$ except for test 30 . During test 30 , only the outer packers were inflated, which made the test-interval length $11.3 \mathrm{~m}$. The borehole penetrated the water table at approximately $489 \mathrm{~m}$ below land surface. The geologic zones tested extended from the crystal-poor lower lithophysal zone of the Tiva Canyon Tuff to the Calico Hills Formation. The Paintbrush Group nonwelded units were not tested because of caving of the borehole wall. Air- injection permeability values ranged from $2.3 \times$ $10^{-14} \mathrm{~m}^{2}$ in the crystal-poor middle nonlithophysal zone of the Topopah Spring Tuff, to $2.7 \times 10^{-11} \mathrm{~m}^{2}$ in the crystal-poor lower nonlithophysal zone of the Tiva Canyon Tuff. Most air-injection permeability values are between $10^{-13} \mathrm{~m}^{2}$ and $10^{-11} \mathrm{~m}^{2}$. The two highest air-injection permeability values, $2.7 \times 10^{-11} \mathrm{~m}^{2}$ and $1.5 \times 10^{-11} \mathrm{~m}^{2}$, were located in the shallow Tiva Canyon crystal-poor lower nonlithophysal zone. Airinjection permeability values of the Topopah Spring Tuff ranged from $2.3 \times 10^{-14} \mathrm{~m}^{2}$ to $9.5 \times 10^{-12} \mathrm{~m}^{2}$. The air-permeability values are in agreement with the borehole UZ-16 values reported by LeCain and Walker (1994). The Topopah Spring crystal-poor upper lithophysal and middle nonlithophysal zones show a distinct decrease in permeability with increased depth. The Topopah Spring lower 


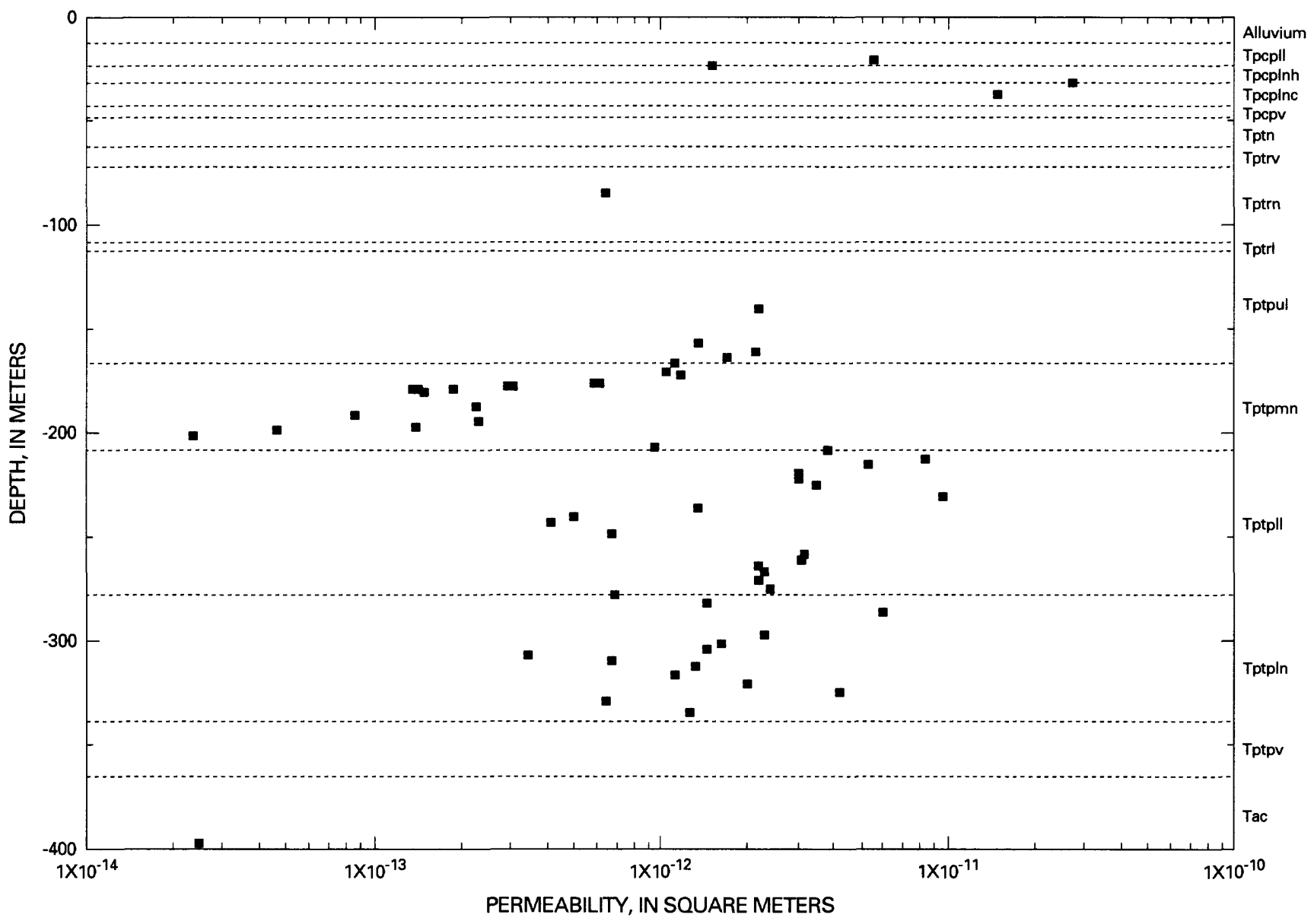

Figure 7. Relation of air-injection permeability values to depth and geologic zone penetrated in borehole UZ-16. 


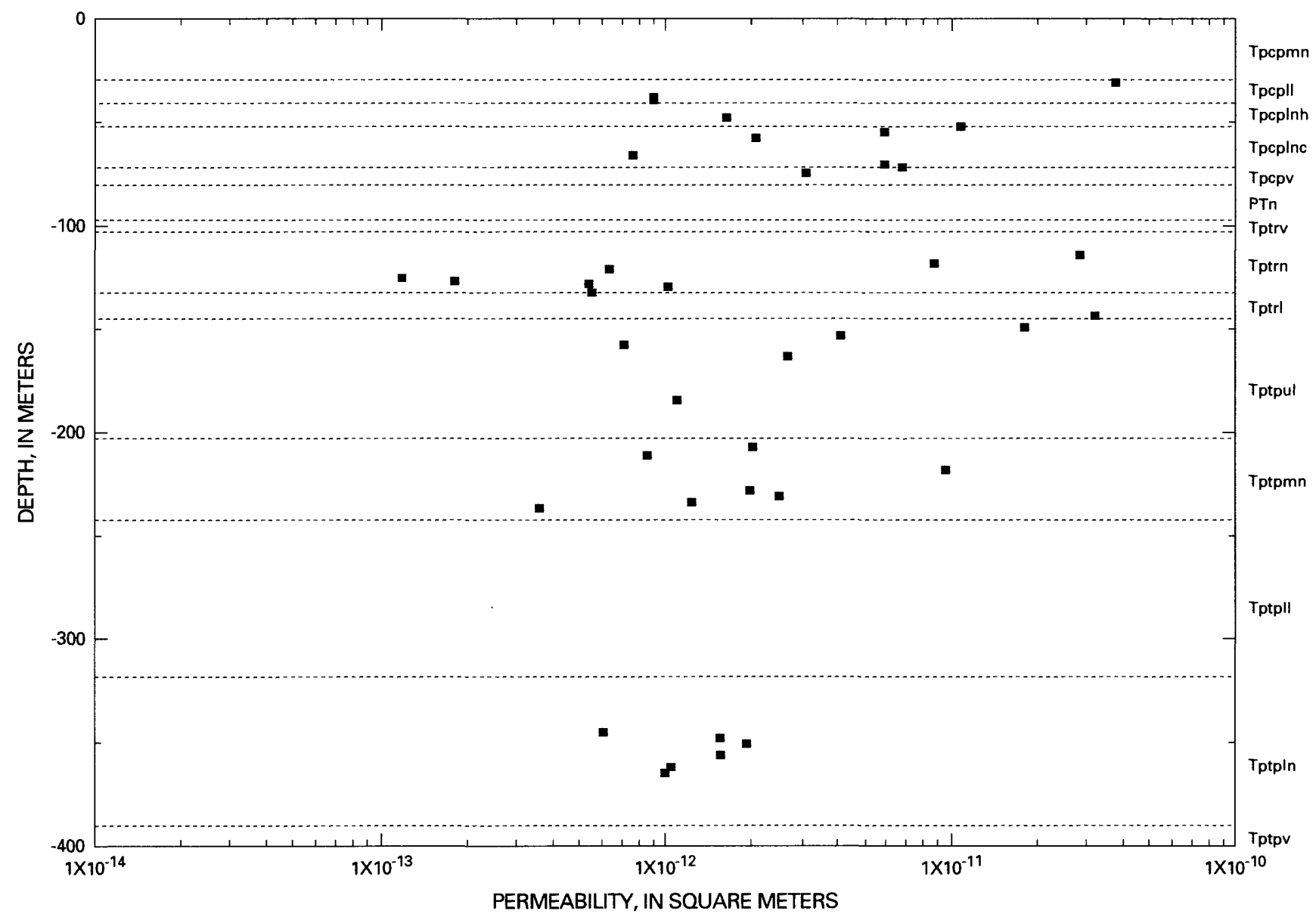

Figure 8. Relation of air-injection permeability values to depth and geologic zone penetrated in borehole SD-12.

12 Alr-Injectlon Testing in Vertical Boreholes In Welded and Nonwelded Tuff, Yucca Mountain, Nevada 


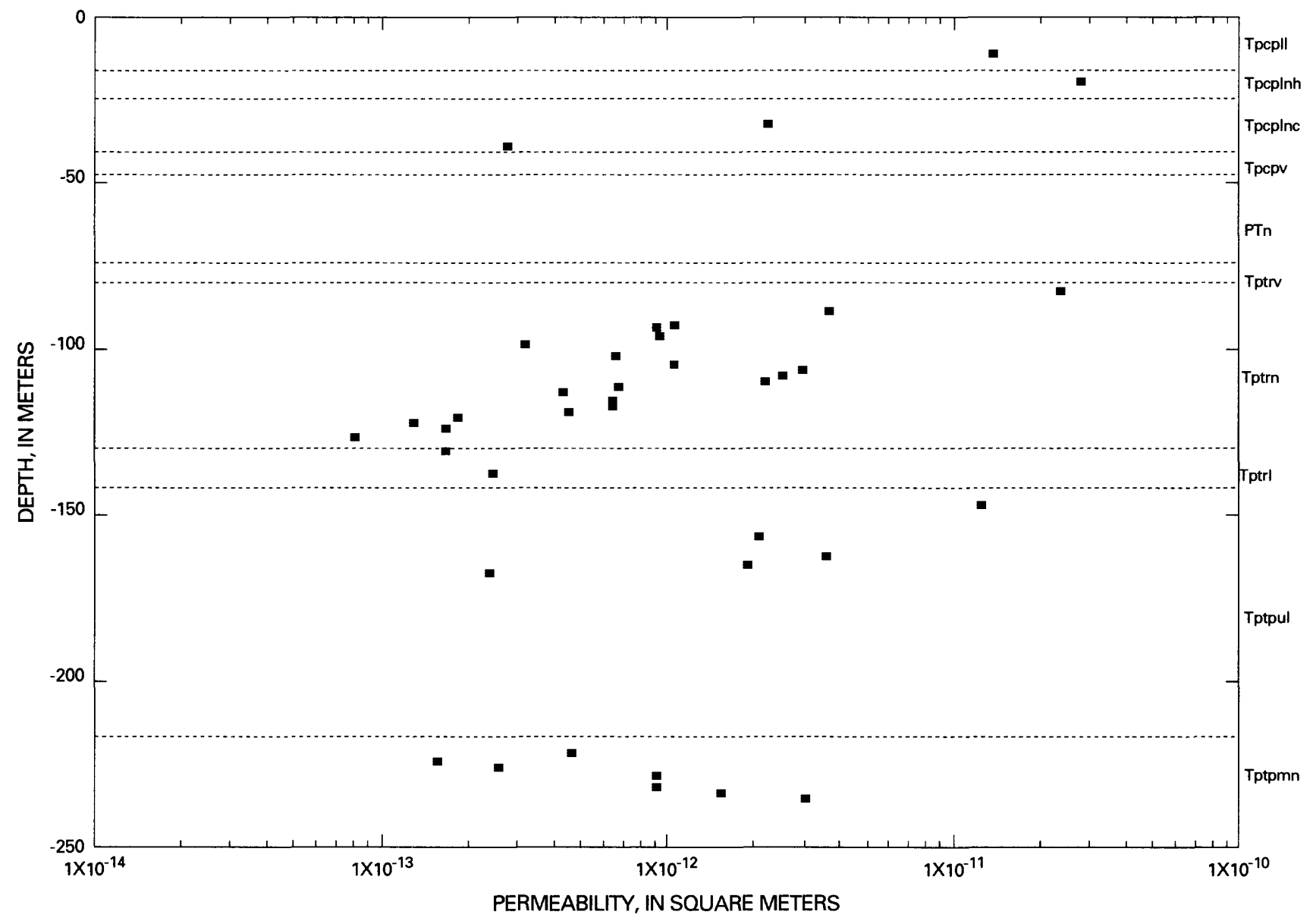

Figure 9. Relation of air-injection permeability values to depth and geologic zone penetrated in borehole NRG-6. 


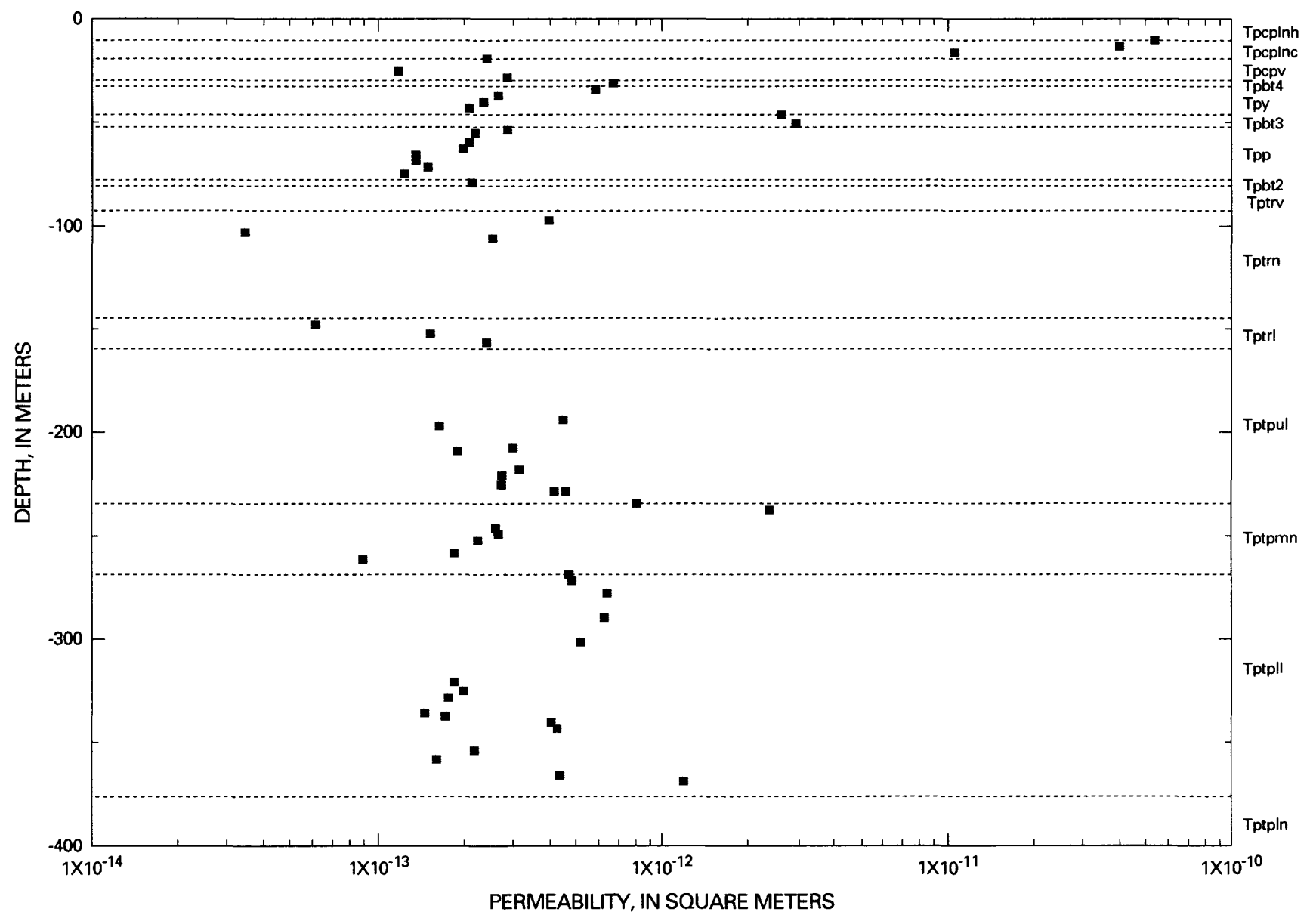

Figure 10. Relation of air-injection permeability values to depth and geologic zone penetrated in borehole NRG-7a. 
lithophysal and lower nonlithophysal zones indicate a decrease in permeability with increased depth. Figure 7 also shows a distinct shift in the air-injection permeability values at the Topopah Spring middle nonlithophysal lower lithophysal contact.

Figure 11 presents an arithmetic plot of absolute pressure with time in the test interval during test 17 , borehole UZ-16. Test 17 was done on the nonwelded Calico Hills Formation. The test interval is a nonwelded, zeolitized tuff with an estimated porosity of 30 percent. The pressure peak at $207.0 \mathrm{kPa}$, and subsequent pressure decline, reflects the transient drainage of water-filled pores and/or fractures. Initially the pores cannot drain fast enough to conduct the injected air; however, with time, water is forced from the pores and/or fractures and the pressure stabilizes at a lower value than the peak of $207.0 \mathrm{kPa}$. Pressure curves that showed transient drainage were identified in borehole UZ-16 tests of the Calico Hills and in borehole SD-12 tests of the Tiva Canyon.

Borehole UZ-16 was the only borehole tested that penetrated the Calico Hills Formation. The figure 11 steady-state pressure of $136.0 \mathrm{kPa}$ gives a calculated permeability value of $1.7 \times 10^{-14} \mathrm{~m}^{2}$. The steady-state pressure can also be used as an upper limit of the test interval pre-test capillary pressure. The steady-state pressure, $136.0 \mathrm{kPa}$, minus the atmospheric pressure, $92.7 \mathrm{kPa}$, means the testinterval capillary pressure was less than $43.3 \mathrm{kPa}$.

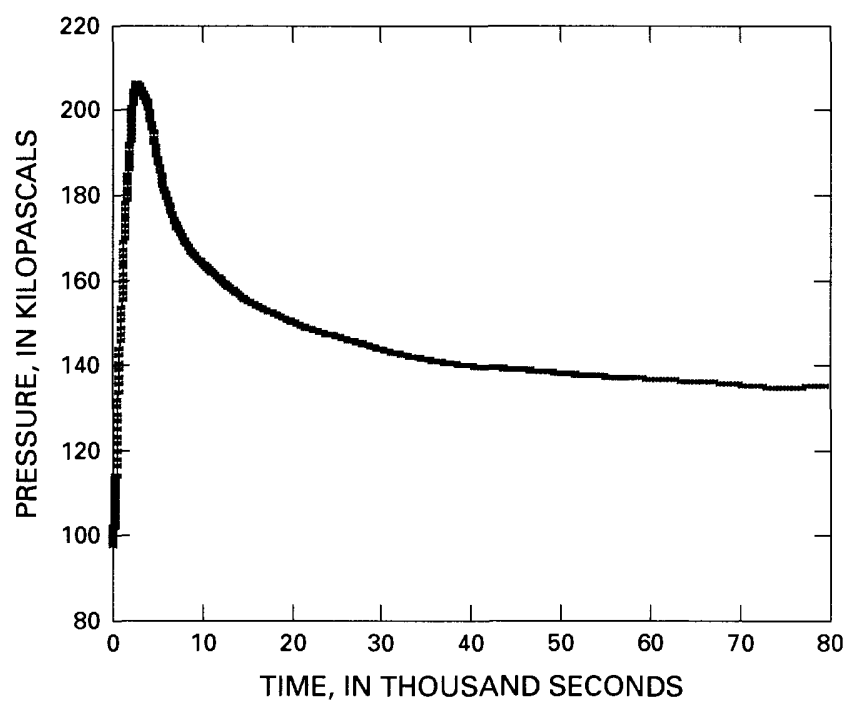

Figure 11. Absolute pressure as a function of time in the test interval during air-injection test 17 , borehole UZ-16.
Tests 19 and 20 (10 and 20 slpm) were done on the same test interval. The tests gave air-injection permeability values of $2.5 \times 10^{-14} \mathrm{~m}^{2}$ and $1.9 \times$ $10^{-14} \mathrm{~m}^{2}$, respectively. The air-injection rates were kept at or below 20 slpm to minimize any additional water movement in the rock. Test 21 was conducted with an air-injection flow rate of $30 \mathrm{slpm}$. As in test 17 , test 21 had a similar pressure response and required 18 hours to stabilize. During test 21 , the peak pressure was lower, $181.0 \mathrm{kPa}$, and the steady-state pressure was higher, $146.0 \mathrm{kPa}$. The peak pressure was lower because the first test had already forced water from most of the pores and/or fractures. The higher steady-state pressure was due to the increased flow rate. The steady-state pressure of test 21 had a calculated permeability value of $2.0 \times 10^{-14} \mathrm{~m}^{2}$. Theoretically, test 21 should have a higher airinjection permeability value than test 17 because the increased air-injection rate will force water out of additional pore space. With an atmospheric pressure of $92.7 \mathrm{kPa}$, the differential pressures for the 20 - and 30 -slpm steady-state tests were 43.3 and $53.3 \mathrm{kPa}$. These capillary pressures correspond to pores with radii and fractures with apertures of approximately 3.3 and $2.7 \mu \mathrm{m}$.

Temperature changes in the test intervals because of gas expansion and (or) transport of surface air to depth were less than $0.5^{\circ} \mathrm{C}$. Temperature changes in the guard zones were less than $0.1^{\circ} \mathrm{C}$.

\section{Borehole SD-12}

The borehole diameter of SD-12 was $0.31 \mathrm{~m}$, and total depth was $335.4 \mathrm{~m}$. The test-interval length was $4.9 \mathrm{~m}$ for tests 1 through 37 and $4.6 \mathrm{~m}$ for tests 38 through 161. Tests were conducted from February 1995 through May 1995. The geologic zones extended from the crystal-poor lower lithophysal zone of the Tiva Canyon Tuff to the crystal-poor lower nonlithophysal zone of the Topopah Spring Tuff. The nonwelded tuff of the Paintbrush Group and the lower lithophysal zone of the Topopah Spring Tuff were not tested because of caving of the borehole wall. Airinjection permeability values ranged from $3.8 \times$ $10^{-11} \mathrm{~m}^{2}$ in the shallow Tiva Canyon crystal-poor lower lithophysal zone to $1.2 \times 10^{-13} \mathrm{~m}^{2}$ in the Topopah Spring crystal-rich nonlithophysal zone. Most air-injection permeability values were between $10^{-11} \mathrm{~m}^{2}$ and $10^{-13} \mathrm{~m}^{2}$. The Topopah Spring crystalrich nonlithophysal and the crystal-poor upper 
lithophysal zones showed decreases in permeability with depth.

Several of the Tiva Canyon tests $(7,10$, and 77$)$ had pressure responses that indicated water was forced from the pores and/or fractures. The pressure responses showed a peak and subsequent pressure decline. The tests indicated that water was present in the Tiva Canyon Tuff at depths of 39.6, 42.4, and $77.1 \mathrm{~m}$. The transient water is probably the result of infiltration from the winter (1995) rainfall. The Tiva Canyon tests required only minutes to peak, decline, and stabilize, compared to hours required for the Calico Hills Formation tests. The difference in the time requirements is probably because the Calico Hills tests injected air into a saturated, or nearly saturated, environment, whereas the Tiva Canyon tests forced air into a predominantly air-filled fracture environment that held a transient water pulse. The redistribution of a transient-water pulse in fractured rock at less than saturation would be much faster than the redistribution through saturated rock.

Temperature changes in the test intervals as a result of gas expansion and (or) transport of surface air to depth generally were less than $0.5^{\circ} \mathrm{C}$ with a maximum of $2.5^{\circ} \mathrm{C}$ measured in test 108 . Temperature changes in the guard intervals were less than $0.1^{\circ} \mathrm{C}$.

\section{Borehole NRG-6}

The borehole diameter of NRG-6 was $0.20 \mathrm{~m}$, and total depth was $332.3 \mathrm{~m}$. The test-interval length was $4.3 \mathrm{~m}$ except for a few tests where only the outside packers were inflated. When only the outside packers were used, the test-interval length was $11.3 \mathrm{~m}$. Tests were conducted during October and November 1994. The geologic zones extended from the crystalpoor lower lithophysal zone of the Tiva Canyon Tuff to the crystal-poor middle nonlithophysal zone of the Topopah Spring Tuff. The Paintbrush Group nonwelded tuffs and much of the lower Topopah Spring crystal-poor upper lithophysal zone were not tested because of caving of the borehole wall. Airinjection permeability values ranged from $2.8 \times$ $10^{-11} \mathrm{~m}^{2}$ in the Tiva Canyon crystal-poor lower lithophysal zone to $8.2 \times 10^{-14} \mathrm{~m}^{2}$ in the Topopah Spring crystal-rich nonlithophysal zone. Most airinjection permeability values were between $10^{-11} \mathrm{~m}^{2}$ and $10^{-13} \mathrm{~m}^{2}$. Sixteen of the test intervals had airinjection permeability values larger than $10^{-12} \mathrm{~m}^{2}$, and four test intervals had values larger than $10^{-11} \mathrm{~m}^{2}$. Of the four test intervals with values larger than $10^{-11} \mathrm{~m}^{2}$, two were within $26 \mathrm{~m}$ of the ground surface. The Topopah Spring crystal-rich nonlithophysal zone showed a distinct decrease in permeability with depth. The Topopah Spring crystal-poor middle nonlithophysal zone showed an increase in permeability with depth.

Temperature changes in the test intervals as a result of gas expansion and (or) transport of surface air to depth were generally less than $0.5^{\circ} \mathrm{C}$ with a maximum of $1.5^{\circ} \mathrm{C}$ measured in test 8 . Temperature changes in the guard intervals were less than $0.2^{\circ} \mathrm{C}$.

\section{Borehole NRG-7a}

The borehole diameter of NRG-7a changed with depth. The borehole diameter was $0.20 \mathrm{~m}$ from the ground surface to $91.5 \mathrm{~m}$ and $0.15 \mathrm{~m}$ from $91.5 \mathrm{~m}$ to $379.9 \mathrm{~m}$. The test-interval lengths of the 0.20 - and 0.15-m diameter sections were 4.3 and $3.5 \mathrm{~m}$, respectively. Tests were conducted from July through September 1994. The geologic zones extended from the crystal-poor lower nonlithophysal zone of the Tiva Canyon Tuff to the crystal-poor lower lithophysal zone of the Topopah Spring Tuff. The borehole wall was in good condition, and most of the 0.20 - and 0.15 -m-diameter sections of the borehole were tested. Air-injection permeability values ranged from $3.5 \times$ $10^{-14} \mathrm{~m}^{2}$ in the Topopah Spring crystal-rich nonlithophysal zone to $5.4 \times 10^{-11} \mathrm{~m}^{2}$ in the Tiva Canyon crystal-poor lower nonlithophysal zone. Most airinjection permeability values were between $10^{-13} \mathrm{~m}^{2}$ and $10^{-12} \mathrm{~m}^{2}$. Seven of the test intervals had values greater than $10^{-12} \mathrm{~m}^{2}$. Of the seven, five were within $60 \mathrm{~m}$ of the ground surface. The three test intervals with air-injection permeability values larger than $10^{-11} \mathrm{~m}^{2}$ were within $20 \mathrm{~m}$ of the ground surface. The Topopah Spring crystal-poor middle nonlithophysal zone shows a decrease in permeability with depth.

Borehole NRG-7a was the only borehole where the borehole wall was in sufficiently good condition to allow tests of the nonwelded tuff of the Paintbrush Group. The nonwelded tuff air-injection permeability values ranged from $1.2 \times 10^{-13} \mathrm{~m}^{2}$ at the bottom of the Pah Canyon Tuff and Tiva Canyon crystal-poor vitric 1 subzone to $3.0 \times 10^{-12} \mathrm{~m}^{2}$ in bedded tuff number 3 . The Yucca Mountain and Pah Canyon Tuffs showed decreases in permeability with depth. 
Temperature changes in the injection intervals as a result of gas expansion and (or) transport of surface air to depth were generally less than $0.5^{\circ} \mathrm{C}$ with a maximum of $1.0^{\circ} \mathrm{C}$ measured in test 40 . Temperature changes in the guard intervals were less than $0.2^{\circ} \mathrm{C}$.

\section{Air-Injection Permeability Values by Geologic Unit}

\section{Tiva Canyon Tuff}

Table 1 presents a statistical summary of the Tiva Canyon Tuff air-injection permeability values by borehole. All the test intervals were located in the lower Tiva Canyon zones; lower lithophysal, lower nonlithophysal, and crystal-poor vitric. The data base

Table 1. Statistical summary of Tiva Canyon Tuff airinjection permeability values by borehole

[Units are $\times 10^{-12}$ square meters]

\begin{tabular}{lccccc}
\hline Borehole & $\begin{array}{c}\text { Number } \\
\text { of } \\
\text { test } \\
\text { Intervals }\end{array}$ & $\begin{array}{c}\text { Arith- } \\
\text { metic } \\
\text { mean }\end{array}$ & $\begin{array}{c}\text { Geo- } \\
\text { met- } \\
\text { ric } \\
\text { mean }\end{array}$ & $\begin{array}{c}\text { Maxi- } \\
\text { mum }\end{array}$ & $\begin{array}{c}\text { Mini- } \\
\text { mum }\end{array}$ \\
\hline UZ-16 & 4 & 12.3 & 7.6 & 27.0 & 1.5 \\
SD-12 & 11 & 7.0 & 3.4 & 38.0 & 0.8 \\
NRG-6 & 4 & 11.2 & 4.1 & 28.0 & 0.3 \\
NRG-7a & $* 4$ & 26.6 & 8.4 & 54.0 & 0.24 \\
\hline
\end{tabular}

is small with only four test intervals in each of boreholes UZ-16, NRG-6, and NRG-7a. The airinjection permeability values ranged from $0.24 \times$ $10^{-12} \mathrm{~m}^{2}$ in NRG-7a to $54.0 \times 10^{-12} \mathrm{~m}^{2}$ in NRG-7a. The mean air-injection permeability value for all borehole was $12.0 \times 10^{-12} \mathrm{~m}^{2}$.

Based on the assumption that the borehole samples are log normally distributed, and have similar variances (two assumptions that cannot be supported by the small data base), an analysis of variance between samples of the natural log air-injection permeability values gives a $p$-value of 0.71 . The $p$-value indicates that the mean permeability values of the four boreholes are not statistically different. The absence of a statistically significant difference between the means may be because there really is no difference or may be the result of the small data base.

Table 2 presents a statistical summary of the Tiva Canyon Tuff air-injection permeability values by geologic zone and borehole. The total number of test intervals in table 2 does not equal the number in table 1 because test intervals that straddled two geologic zones are not included in table 2.

Figure 12 presents histograms and basic statistics of the Tiva Canyon Tuff air-injection permeability values by borehole. Figure 13 presents histograms and basic statistics of the Tiva Canyon Tuff natural log air-injection permeability values by borehole. Because the data base for each borehole is small, it is impossible to reach any conclusions about the individual borehole population distributions.

Table 2. Statistical summary of Tiva Canyon Tuff air-injection permeability values by geologic zone and borehole

[Units are $\times 10^{-12}$ square meters; mean is arithmetic mean; \# is number of test intervals; st. dev. is standard deviation; NA is not applicable; -- is no data]

\begin{tabular}{|c|c|c|c|c|}
\hline Geologic zone & $\begin{array}{l}\text { Borehole UZ-16 } \\
\text { mean (\#) st. dev. }\end{array}$ & $\begin{array}{l}\text { Borehole SD-12 } \\
\text { mean (\#) st. dev. }\end{array}$ & $\begin{array}{l}\text { Borehole NRG-6 } \\
\text { mean (\#) st. dev. }\end{array}$ & $\begin{array}{l}\text { Borehole NRG-7a } \\
\text { mean (\#) st. dev. }\end{array}$ \\
\hline \multirow[t]{3}{*}{ Lower lithophysal } & 5.5 & 19.6 & 14.0 & \\
\hline & (1) & (2) & (1) & -- \\
\hline & NA & 18.7 & NA & $\cdot$ \\
\hline \multirow[t]{3}{*}{ Lower nonlithophysal hackly } & & 1.7 & & \\
\hline & -- & $(1)$ & -- & -- \\
\hline & & & & \\
\hline \multirow[t]{3}{*}{ Lower nonlithophysal columnar } & 15.0 & 2.9 & 1.3 & 25.7 \\
\hline & (1) & (3) & (2) & (2) \\
\hline & NA & 2.2 & 1.0 & 14.9 \\
\hline \multirow[t]{3}{*}{ Crystal-poor vitric } & & & & 0.2 \\
\hline & - & -- & -- & (2) \\
\hline & & & & 0.1 \\
\hline
\end{tabular}



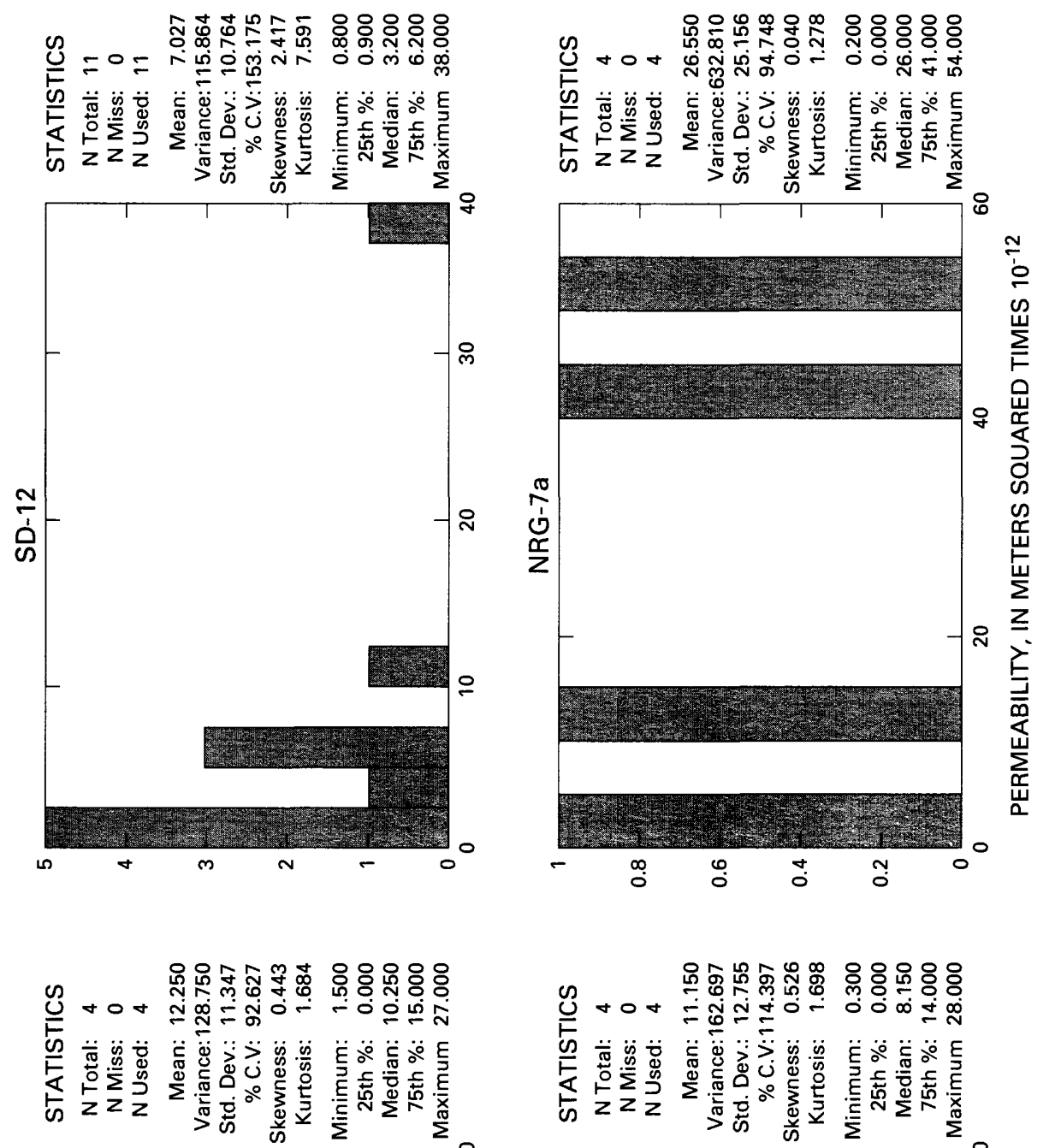

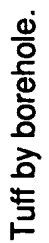
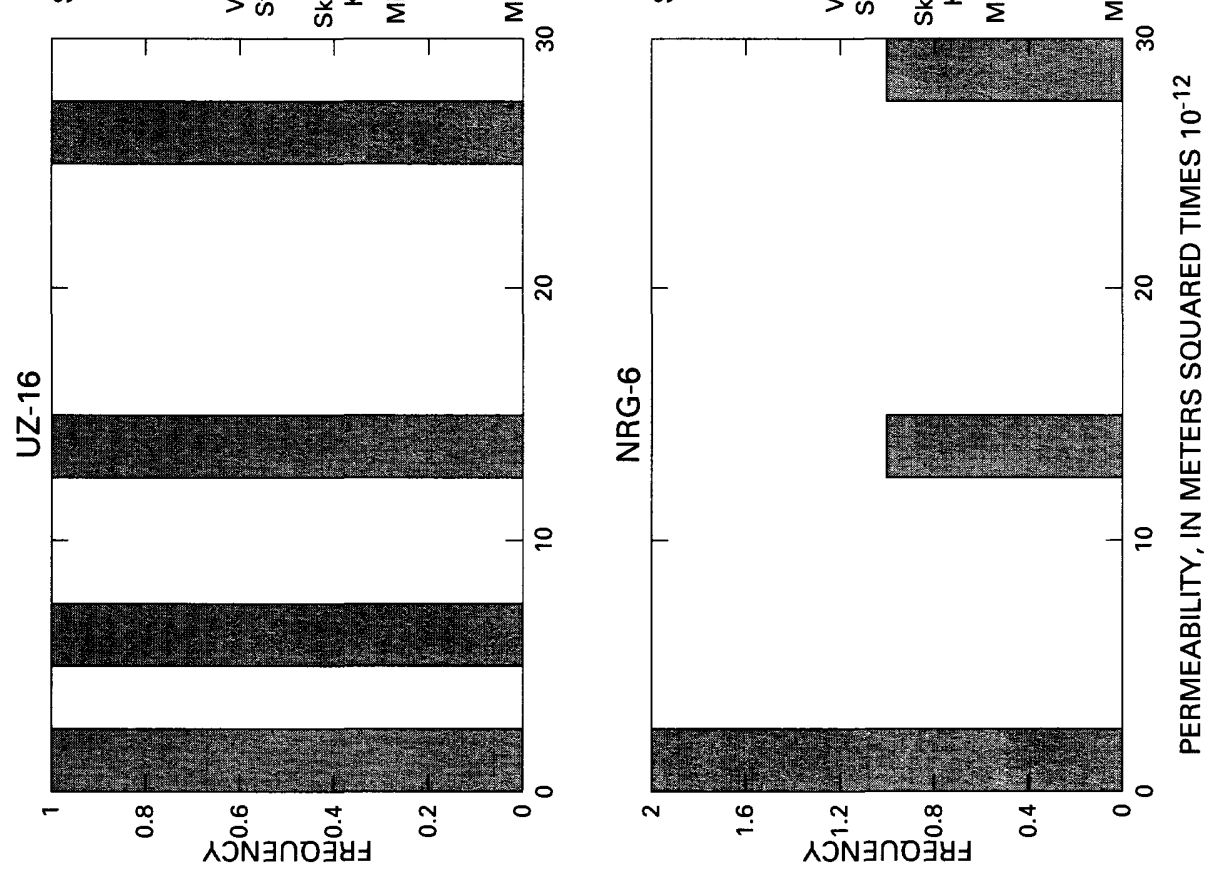

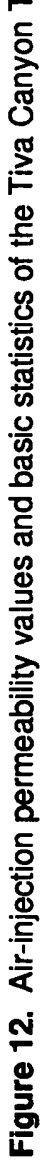



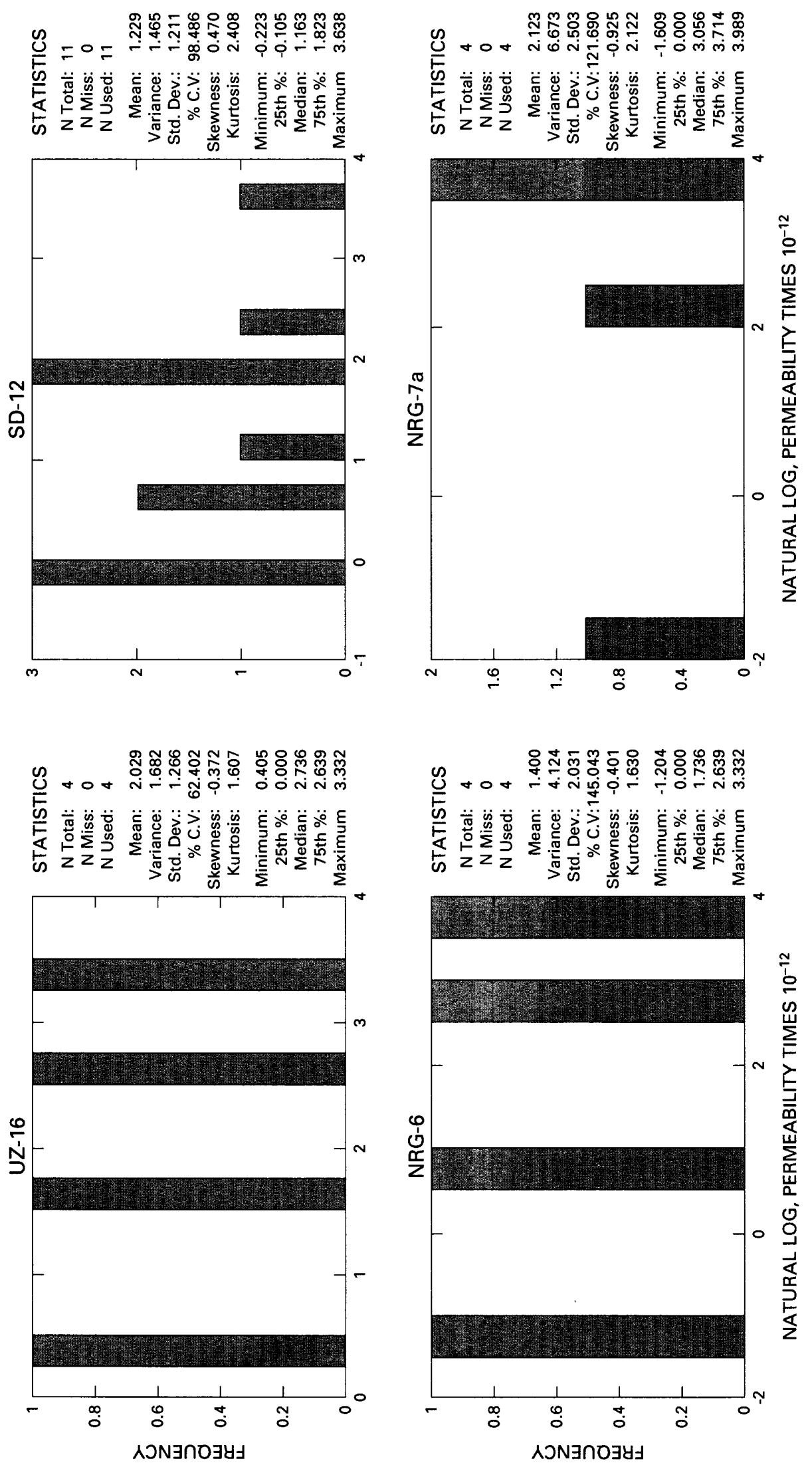

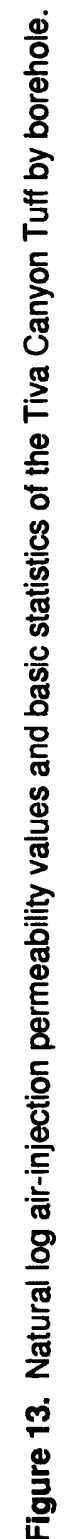




\section{Nonwelded Tuff of the Paintbrush Group}

Table 3 presents a statistical summary of the airinjection permeability values of the nonwelded tuff of the Paintbrush Group. All values are from borehole NRG-7a. The summary includes test intervals in the Yucca Mountain Tuff, Pah Canyon Tuff, bedded tuffs 2,3 , and 4, and two test intervals in the crystal-poor nonwelded vitric zone of the Tiva Canyon Tuff. The nonwelded tuff air-injection permeability values ranged from $1.2 \times 10^{-13} \mathrm{~m}^{2}$ at the bottom of the Pah Canyon Tuff and the crystal-poor vitric zone of the Tiva Canyon Tuff to $3.0 \times 10^{-12} \mathrm{~m}^{2}$ in bedded tuff number 3 . The mean air-injection permeability value was $0.54 \times 10^{-12} \mathrm{~m}^{2}$.

Table 3. Statistical summary of the air-injection permeability values of the nonwelded tuff of the Paintbrush Group

\begin{tabular}{lcllll} 
[Units are $\times 10^{-12}$ square meters] \\
\hline Borehole & $\begin{array}{c}\text { Number of } \\
\text { test } \\
\text { Intervals }\end{array}$ & $\begin{array}{c}\text { Arlth- } \\
\text { metic } \\
\text { mean }\end{array}$ & $\begin{array}{c}\text { Geo- } \\
\text { metric } \\
\text { mean }\end{array}$ & $\begin{array}{c}\text { Maxl- } \\
\text { mum }\end{array}$ & $\begin{array}{c}\text { Mlnl- } \\
\text { mum }\end{array}$ \\
\hline NRG-7a & $* 18$ & 0.54 & 0.30 & 3.0 & 0.12 \\
\hline
\end{tabular}

*Includes two test intervals from the crystal-poor nonwelded vitric zone of the Tiva Canyon Tuff.

Table 4 presents a statistical summary of the airinjection permeability values of the nonwelded tuff of the Paintbrush Group by geologic zone. Test intervals that straddle geologic zones are not included.

Exceptions were made for the bedded units 2 and 4 test intervals, which were thinner than the length of the test interval.

Figure 14 presents the air-injection permeability values of the nonwelded tuff of the Paintbrush Group with depth. The largest air-injection permeability value $\left(3.0 \times 10^{-12} \mathrm{~m}^{2}\right)$ was in the bedded tuff number 3 ; the lowest value $\left(0.12 \times 10^{-12} \mathrm{~m}^{2}\right)$ was in the crystal-poor vitric zone of the Tiva Canyon Tuff and in the lower Pah Canyon Tuff. The Agapito and Associates geology and rock-structure log (Agapito and Associates, written commun., 1996) describes the bedded tuff number 3 as "course grained and weakly consolidated" with no fractures. The absence of fractures indicates that flow in the bedded number 3 is through the matrix. The Agapito and Associates geology and rock-structure log describes the Tiva Canyon crystal-poor vitric test interval as a welding transition zone. The low permeability is probably the
Table 4. Statistical summary of the air-injection permeability values of the nonwelded tuff of the Paintbrush Group by geologic zone

[Units are $\times 10^{-12}$ square meters; NA is not applicable]

\begin{tabular}{cc}
\hline Geologlc zone & $\begin{array}{c}\text { Borehole NRG-7a } \\
\text { arlthmetlc mean } \\
\text { (number of Intervals) } \\
\text { standard devlation }\end{array}$ \\
\hline Tiva Canyon crystal-poor vitric & 0.2 \\
& $(2)$ \\
Bedded tuff \#4 & 0.12 \\
& 0.2 \\
Yucca Mountain Tuff & $(1)$ \\
NA \\
Bedded tuff \#3
\end{tabular}

result of partial welding. The Yucca Mountain and Pah Canyon Tuffs both showed decreased permeability with increased depth. The Agapito and Associates geology and rock-structure log describes the Yucca Mountain Tuff as "weak to partially welded." The logs do not report welding in the Pah Canyon Tuff.

Figure 15 is a histogram showing the airinjection permeability values of the nonwelded tuff of the Paintbrush Group. Most of the air-injection permeability values plot on the left. The distribution is skewed right by the bedded tuff number 3 values. Figure 16 is a histogram showing the natural log airinjection permeability values of the nonwelded tuff of the Paintbrush Group. The natural log plot is also skewed right, but the distribution is reasonably log normal. 


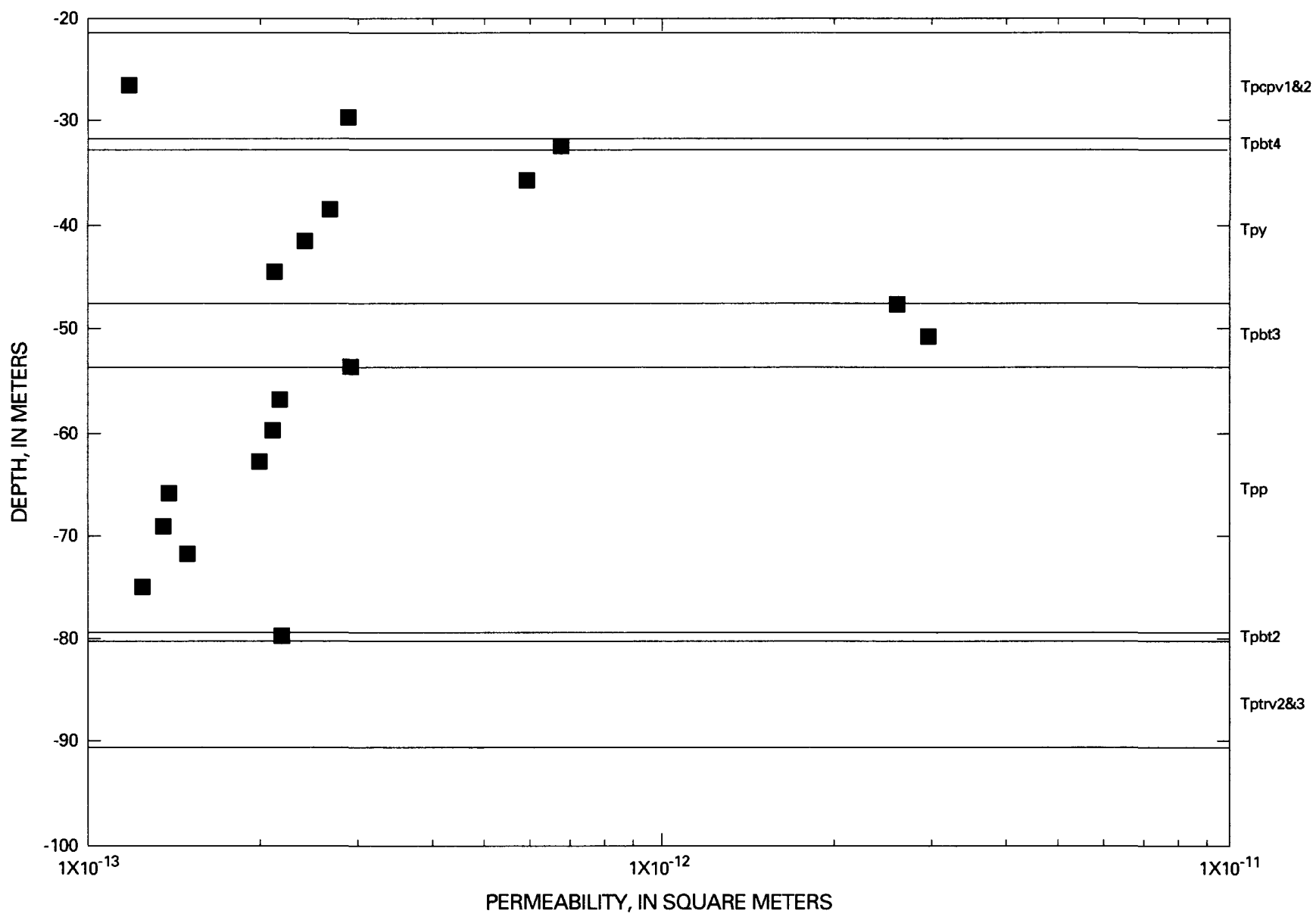

Figure 14. Air-injection permeability values of the nonwelded tuff of the Paintbrush Group with depth, borehole NRG-7a.

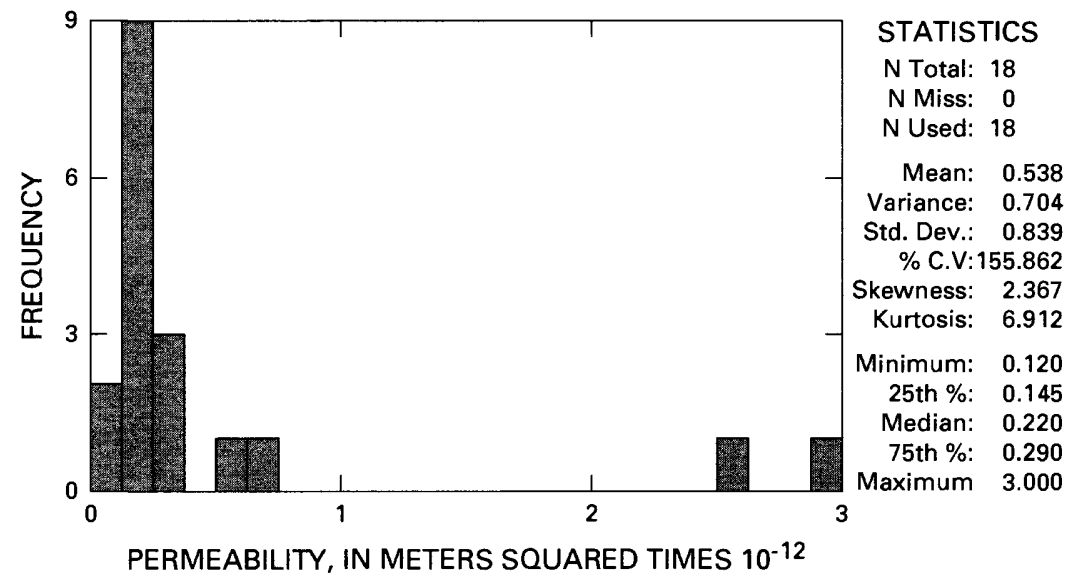

Figure 15. Air-injection permeability values of the nonwelded tuff of the Paintbrush Group, borehole NRG-7a. 


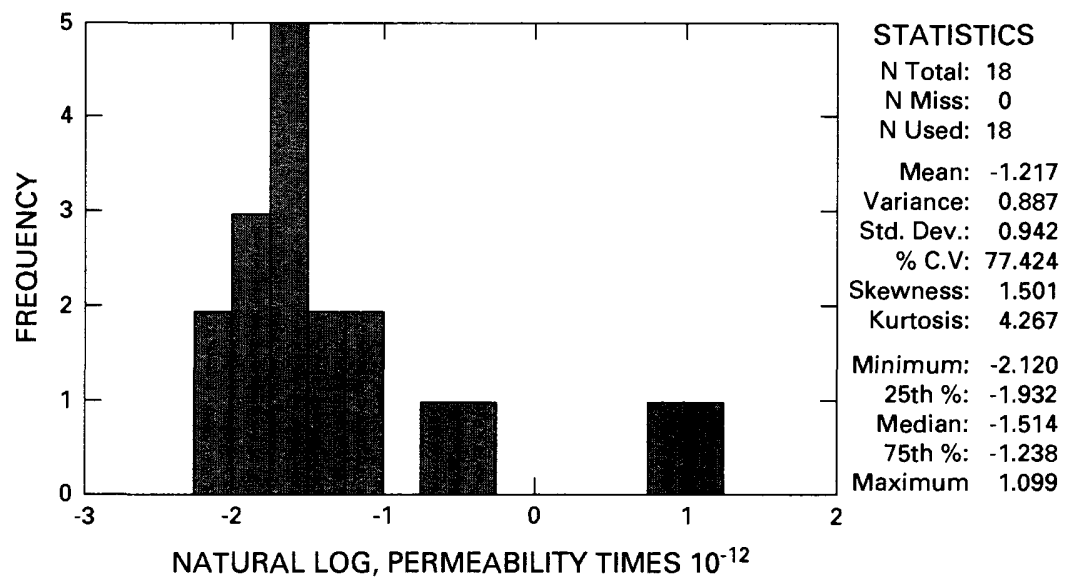

Figure 16. Natural log air-injection permeability values of the nonwelded tuff of the Paintbrush Group, borehole NRG-7a.

\section{Topopah Spring Tuff}

Table 5 presents a statistical summary of the Topopah Spring Tuff air-injection permeability values by borehole. The permeability values ranged from $0.02 \times 10^{-12} \mathrm{~m}^{2}$ in the crystal-poor middle nonlithophysal zone of UZ-16, to $33.0 \times 10^{-12} \mathrm{~m}^{2}$ in the crystal-rich lithophysal zone of SD-12. The borehole mean permeability values ranged an order of magnitude from $4.7 \times 10^{-12} \mathrm{~m}^{2}$ in borehole SD-12, to $0.4 \times 10^{-12} \mathrm{~m}^{2}$ in borehole NRG-7a.

Table 5. Statistical summary of Topopah Spring Tuff air-injection permeability values by borehole

[Units are $\times 10^{-12}$ square meters]

\begin{tabular}{lccccc}
\hline Borehole & $\begin{array}{c}\text { Number } \\
\text { of test } \\
\text { intervals }\end{array}$ & $\begin{array}{c}\text { Arlth- } \\
\text { metic } \\
\text { mean }\end{array}$ & $\begin{array}{c}\text { Geo- } \\
\text { metric } \\
\text { mean }\end{array}$ & $\begin{array}{c}\text { Maxi- } \\
\text { mum }\end{array}$ & $\begin{array}{l}\text { Minl- } \\
\text { mum }\end{array}$ \\
\hline UZ-16 & 54 & 1.8 & 0.9 & 9.5 & 0.02 \\
SD-12 & 27 & 4.7 & 1.7 & 33.0 & 0.12 \\
NRG-6 & 34 & 2.1 & 0.8 & 24.0 & 0.08 \\
NRG-7a & 38 & 0.4 & 0.3 & 2.4 & 0.04 \\
\hline
\end{tabular}

Table 6 presents a statistical summary of the Topopah Spring Tuff air-injection permeability values by geologic zone and borehole. Test intervals that straddled geologic zones are not included in table 6 .

The Topopah Spring Tuff data base is larger than the Tiva Canyon Tuff and Paintbrush Group nonwelded tuff data bases, and this allowed additional statistical analysis. Figure 17 presents histograms of the Topopah Spring Tuff air-injection permeability values and basic statistics by borehole. The histograms show that the distributions are not normal. Most of the air-injection permeability values plot on the left. The distributions are skewed right by a limited number of higher permeability values.

Figure 18 presents histograms showing the natural $\log$ air-injection permeability values and basic statistics of the Topopah Spring Tuff by borehole. The plots show that the natural log permeability values could be considered normally distributed. Analysis of variance between the boreholes gives a p-value less than 0.01 ; this indicates that, at a 99 -percent confidence level, at least one of the natural log permeability-value means is statistically different. Examination of figures 17 and 18 indicates that the borehole NRG-7a permeability values are generally smaller than those for the other boreholes. The borehole NRG-7a histogram is shifted to the left and has a smaller variance. Analysis of variance between boreholes of the natural-log values from boreholes UZ-16, SD-12, and NRG-6 gives a p-value of 0.10. A $p$-value of 0.10 indicates acceptance of the null hypothesis that there is no difference among the geometric means of boreholes UZ-16, SD-12, and NRG-6; this indicates that borehole NRG-7a sampled a different population.

Figure 19 presents variograms showing the Topopah Spring Tuff natural log air-injection permeability values by borehole. The variograms use the natural log air-injection permeability values and a minimum pair number of 20 . The lag distance for boreholes UZ-16, NRG-6, and NRG-7a is $10 \mathrm{~m}$. A $15-\mathrm{m}$ lag was used for borehole SD-12 because of its small data base. The range of variogram values of boreholes UZ-16, SD-12, and NRG-6 was similar. 
Table 6. Statistical summary of Topopah Spring Tuff air-injection permeability values by geologic zone and borehole

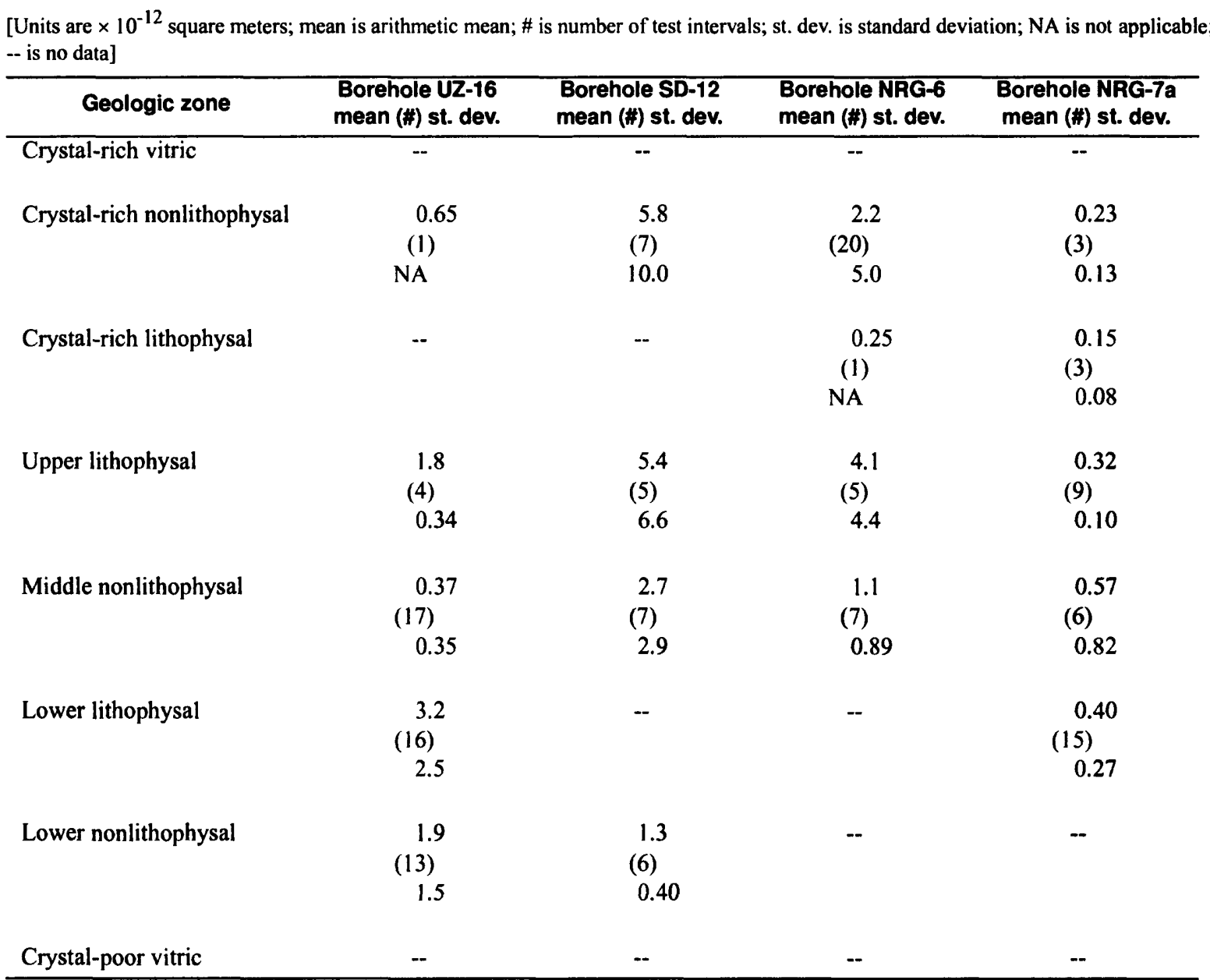

The range of variogram values of borehole NRG-7a was smaller than the other three boreholes. The variograms of boreholes UZ-16, NRG-6 and SD-12 showed a hole effect; an initial increase in the variogram values followed by a decrease. The hole effect was the result of the decrease in permeability with depth that was identified in several geologic zones. The hole effect indicates a structural effect on the permeability distribution, possibly associated with the deposition and cooling of the tuff.

\section{RELATION OF FRACTURE DENSITY, LITHOPHYSAL CAVITIES, AND CORE RECOVERY TO AIR-INJECTION PERMEABILITY}

Table 7 presents the average number of natural fractures per test interval, by geologic unit and borehole, as identified in the structural logs. The fracture data for boreholes UZ-16 and SD-12 are from the Yucca Mountain Project Sample Management Facility structural logs (YMP SMF, written commun., 1996), and the fracture data for boreholes NRG-6 and NRG-7a are from the Agapito \& Associates geology and rock structure logs (Agapito and Associates, written commun., 1996).

Borehole NRG-7a had the highest percentage of missing core. Attempts were made to correct for the missing core. The correction assumed a linear relation between the fracture density of the core present and the fracture density of the missing core. The correction does not correct for potential bias such as the potential for increased fractures in the missing core sections. Based on the linear correction, the borehole NRG-7a Tiva Canyon Tuff average fracture density increased to 22, and the Topopah Spring Tuff increased to 8 . 

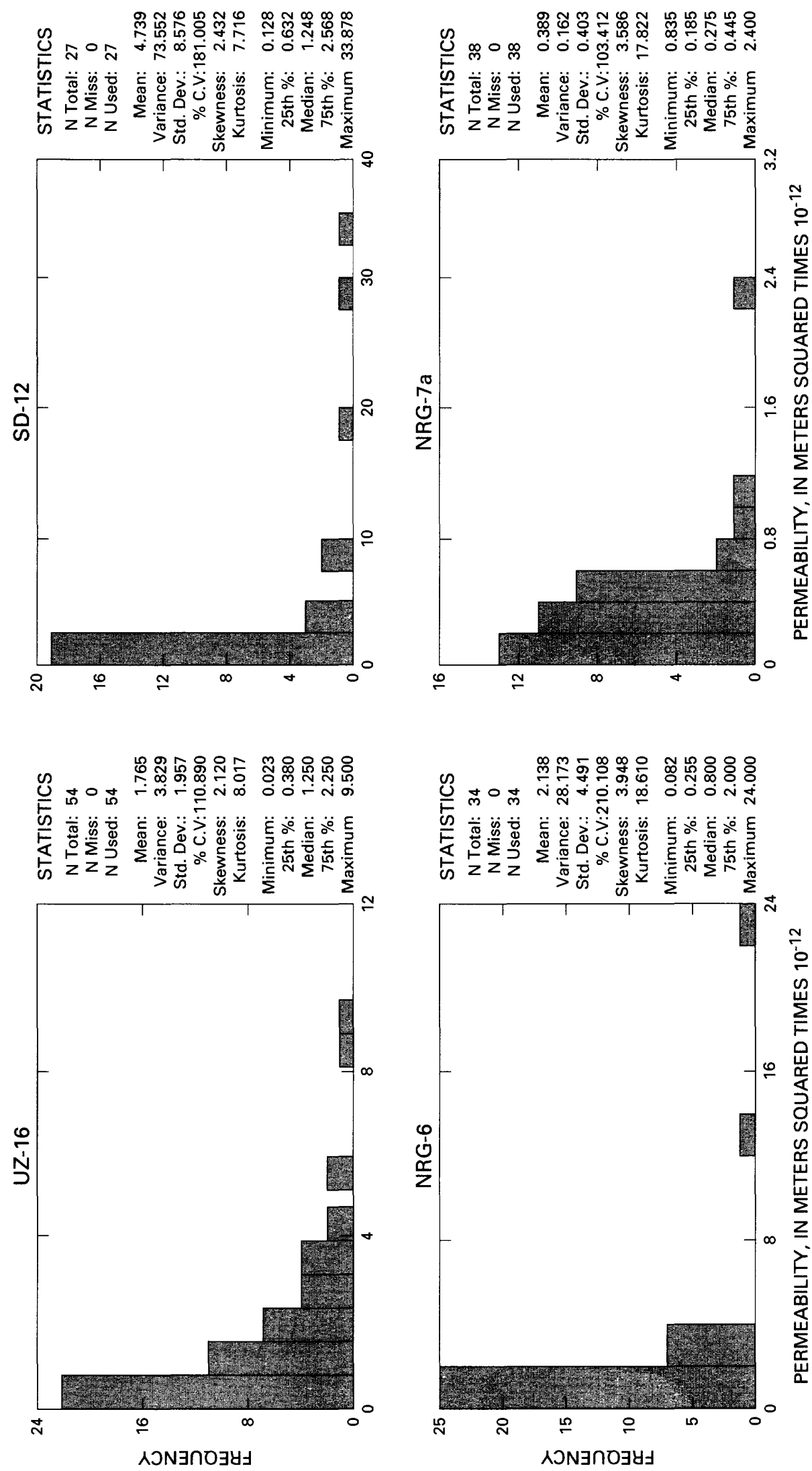

$\frac{1}{0}$
$\frac{0}{10}$
8
$\frac{0}{0}$
5
5
$\frac{5}{5}$
$\frac{2}{2}$
क 

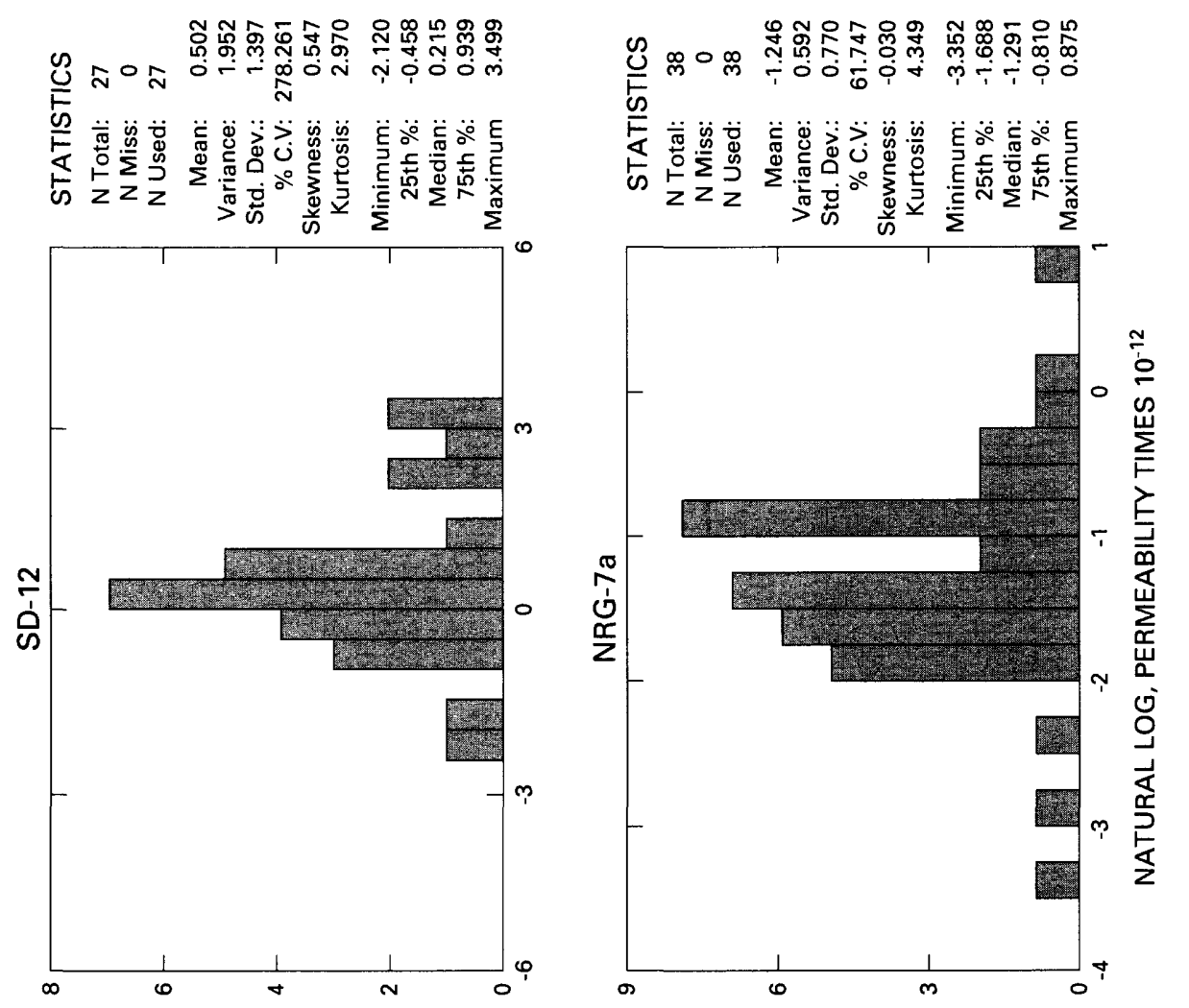

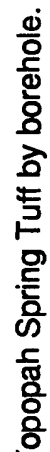
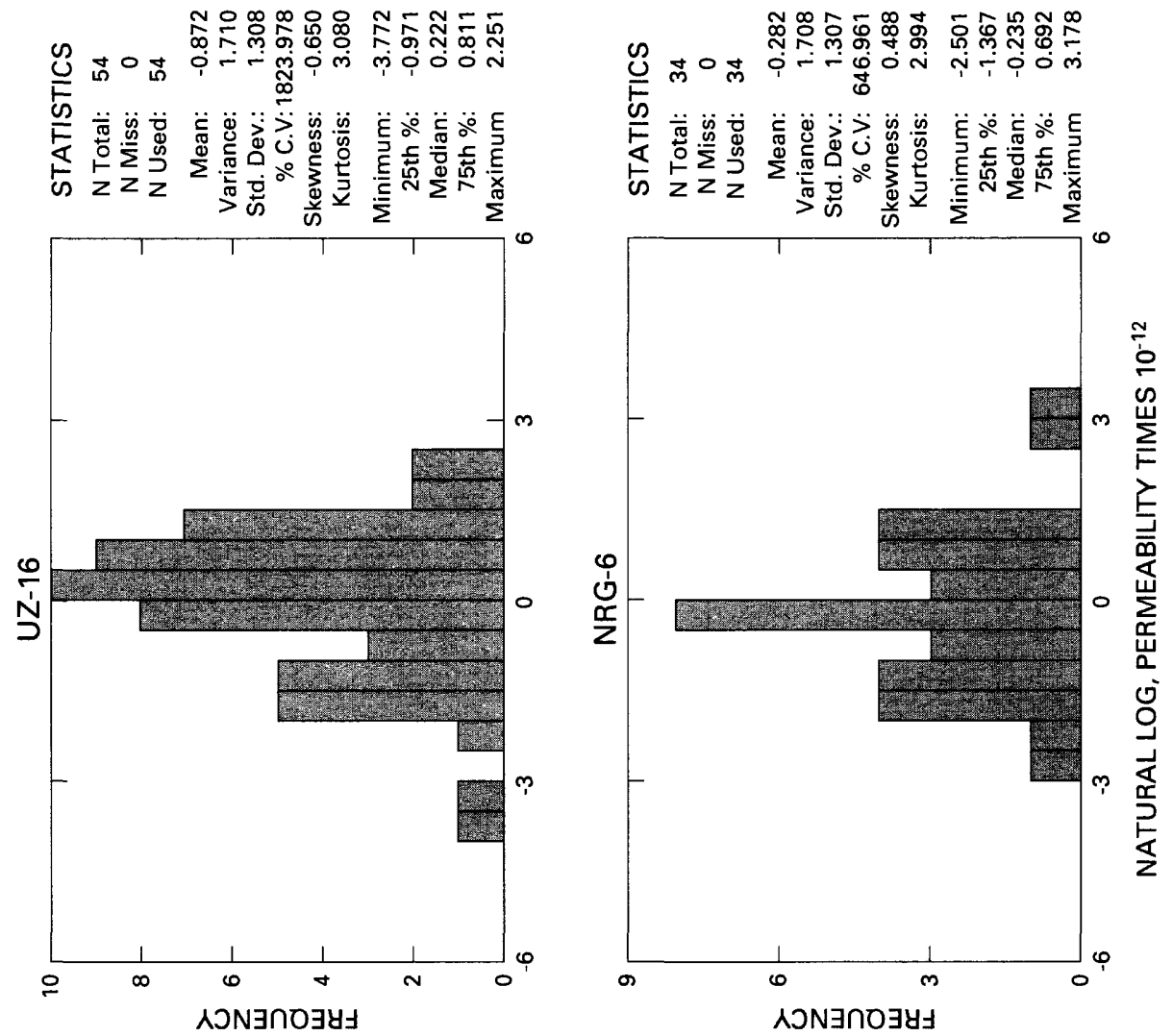

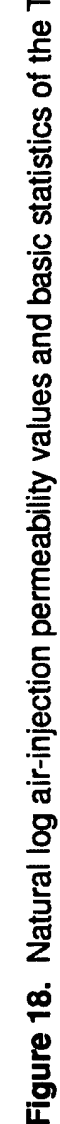


UZ-16

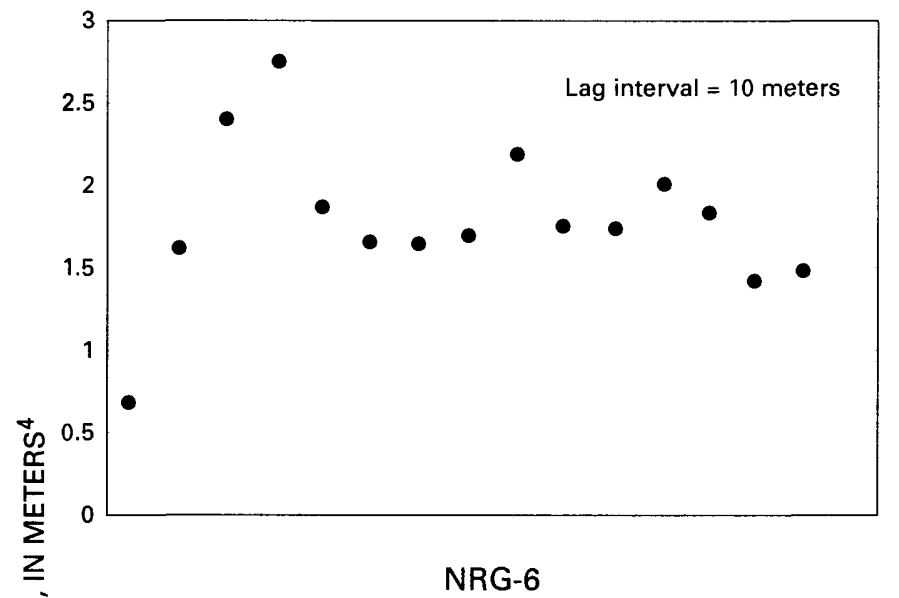

$\sum_{\sum}^{\mathbb{i}}$

$\sum_{0}^{\infty}$

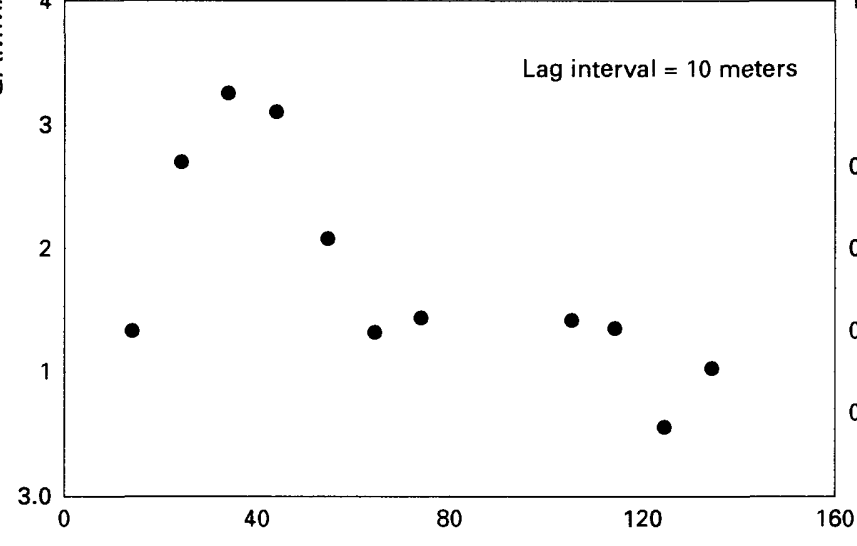

SD-12

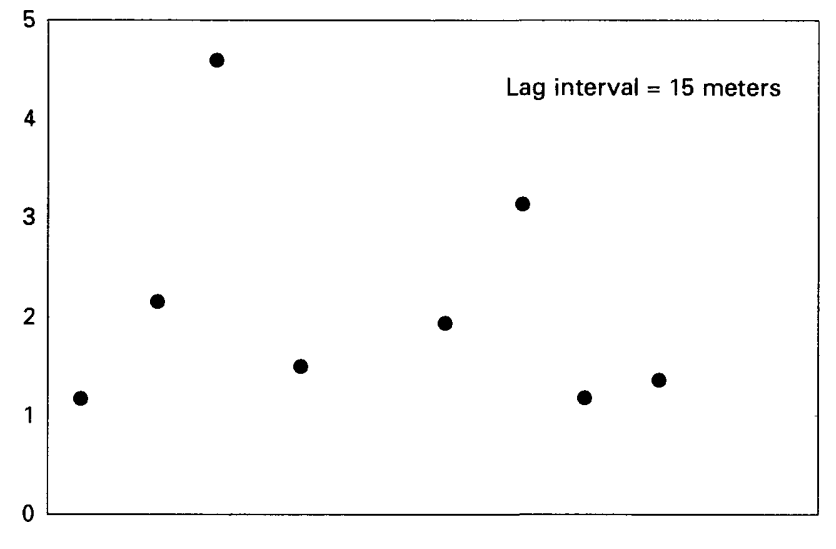

NRG-7a

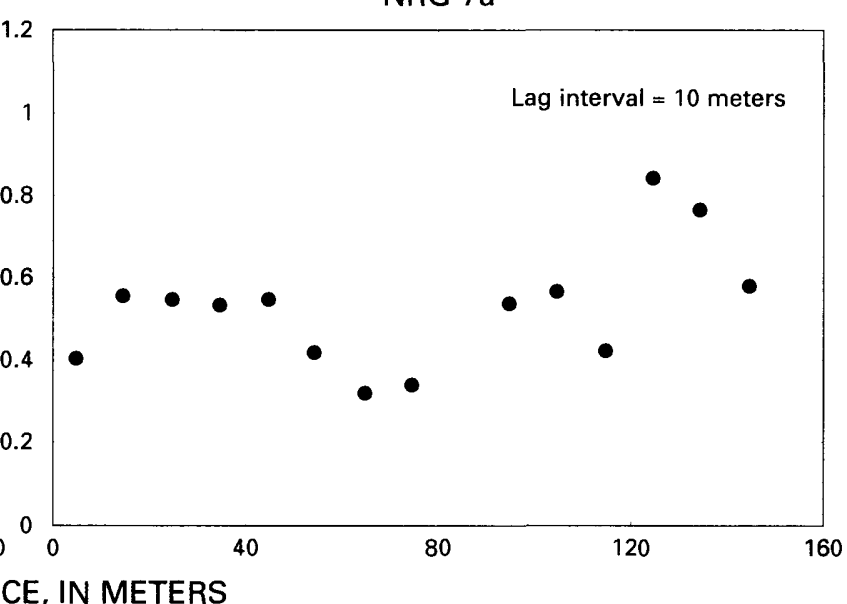

Figure 19. Natural log air-injection permeability values of the Topopah Spring Tuff by borehole.

Table 7. Average number of natural fractures per test interval by geologic unit and borehole [\# fractures is number of fractures; \# intervals is number of test intervals; -- is no data]

\begin{tabular}{lcccc}
\hline Geologlc unlt & $\begin{array}{c}\text { Borehole UZ-16 } \\
\text { \# fractures } \\
\text { (\# Intervals) }\end{array}$ & $\begin{array}{c}\text { Borehole SD-12 } \\
\text { \# fractures } \\
\text { (\# Intervals) }\end{array}$ & $\begin{array}{c}\text { Borehole NRG-6 } \\
\text { \# fractures } \\
\text { (\# Intervals) }\end{array}$ & $\begin{array}{c}\text { Borehole NAG-7a } \\
\text { \# fractures } \\
\text { (\# Intervals) }\end{array}$ \\
\hline Tiva Canyon & 16 & 11 & 23 & 19 \\
Nonwelded tuff & $(4)$ & $(11)$ & $(4)$ & $(4)$ \\
Topopah Spring & -- & -- & -- & 2 \\
& 14 & & & $(18)$ \\
& $(54)$ & 16 & 6 & 4 \\
& & $(27)$ & $(34)$ & $(38)$ \\
\hline
\end{tabular}


The nonwelded tuff of the Paintbrush Group average of two fractures per test interval in borehole NRG-7a can be quantified as Yucca Mountain Tuff, four fractures per test interval; Pah Canyon Tuff, two fractures per test interval; and the bedded units, zero fractures per test interval.

Although there are problems with the core data, the data can be used for comparisons, if one assumes that any potential bias is independent of formation. Table 7 indicates that boreholes UZ-16 and SD-12 have similar fracture densities in the Tiva Canyon and Topopah Spring Tuffs. Boreholes NRG-6 and NRG-7a have Tiva Canyon Tuff fracture densities approximately four times larger than their Topopah Spring Tuff fracture densities. The NRG boreholes are both located on the edge of Drill Hole Wash at the northern end of the repository area. Boreholes UZ-16 and SD-12 are located in the southern part of the repository area. Although no geographic reason has been identified, the difference in fracture density may be related to location. Another possible explanation is a methods bias. The cores of the NRG boreholes were logged and the fractures quantified by Agapito and Associates. The cores of boreholes UZ-16 and SD-12 were logged and the fractures quantified by the Yucca Mountain Project Sample Management Facility. The potential for bias from different methodologies should be considered.

Table 8 presents the goodness-of-fit values $\left(\mathrm{R}^{2}\right)$ from six univariate regression analysis between the air-injection permeability values and six explanatory variables (total fractures, natural fractures, indeterminate fractures, and percentages of lithophysal cavities, core rubble, and core lost). The UZ-16 and SD-12 structural logs did not include the percentage of lithophysal cavities, core rubble, nor core lost. Table 8 shows no correlation between permeability and the number of indeterminate fractures, percentage of lithophysal cavities, core rubble, nor core lost. The regression analysis shows a 0.22 and 0.24 goodnessof-fit between the number of natural fractures and permeability for boreholes NRG-6 and NRG-7a. Figures 20 and 21 are semilog plots of boreholes NRG-6 and NRG-7a air-injection permeability values with the number of natural fractures per test interval.

Fracture analyses of the North Ramp (L. Anna, U.S. Geological Survey, written commun., 1996) indicate that the Topopah Spring Tuff is dominated by two near-vertical fracture sets. The first set has an average strike of 206 degrees and dip of 85 degrees; the second set has an average strike of 180 degrees and dip of 80 degrees. Fractures with dips less than 45 degrees account for less than 10 percent of the total fractures. The Tiva Canyon Tuff is dominated by three near-vertical fracture systems. Fractures with dips less than $\mathbf{4 5}$ degrees account for less than 5 percent of the total fractures. The fracture data indicate that the Topopah Spring and Tiva Canyon Tuffs are anisotropic with respect to permeability.

The Agapito and Associates geology and rock structure logs of boreholes NRG-6 and NRG-7a indicate that few fractures have infilling and that the few with infilling are limited to shallow depths. The infilling of fractures encountered in borehole NRG-7a at depths less than $8 \mathrm{~m}$ was mostly thin, with a few very thin (surface sheen). Infilling at depths from 8 to $25 \mathrm{~m}$ was mostly very thin with a few thin; at depths greater than $25 \mathrm{~m}$, the infilling is very thin or absent. Infilling of fractures in borehole NRG-6 is similar-a few moderately thick near the surface and thin and very thin with depth; this indicates that most fractures are open to gas and liquid flow.

Table 8. Goodness-of-fit values from univariate regression analysis between air-injection permeability values and six explanatory variables

\begin{tabular}{lcccc}
{$\left[\mathbf{R}^{2}\right.$ is the goodness-of-fit in percent; < is less than; -- is no data] } & & \\
\hline \multicolumn{1}{c}{ Independent variable } & $\begin{array}{c}\text { Borehole UZ-16 } \\
\mathbf{R}^{\mathbf{2}}\end{array}$ & $\begin{array}{c}\text { Borehole SD-12 } \\
\mathbf{R}^{\mathbf{2}}\end{array}$ & $\begin{array}{c}\text { Borehole NRG-7a } \\
\mathbf{R}^{\mathbf{2}}\end{array}$ & $\begin{array}{c}\text { Borehole NRG-6 } \\
\mathbf{R}^{\mathbf{2}}\end{array}$ \\
\hline Number of total fractures & $<1$ & 3 & 21 & 10 \\
Number of natural fractures & $<1$ & 5 & 24 & 22 \\
Number of indeterminate fractures & $<1$ & -3 & 4 & $<1$ \\
Lithophysal cavities (percent) & -- & -- & 1 & 1 \\
Core rubble (percent) & -- & -- & 1 & $<1$ \\
Core lost (percent) & -- & -- & 4 & $<1$ \\
\hline
\end{tabular}




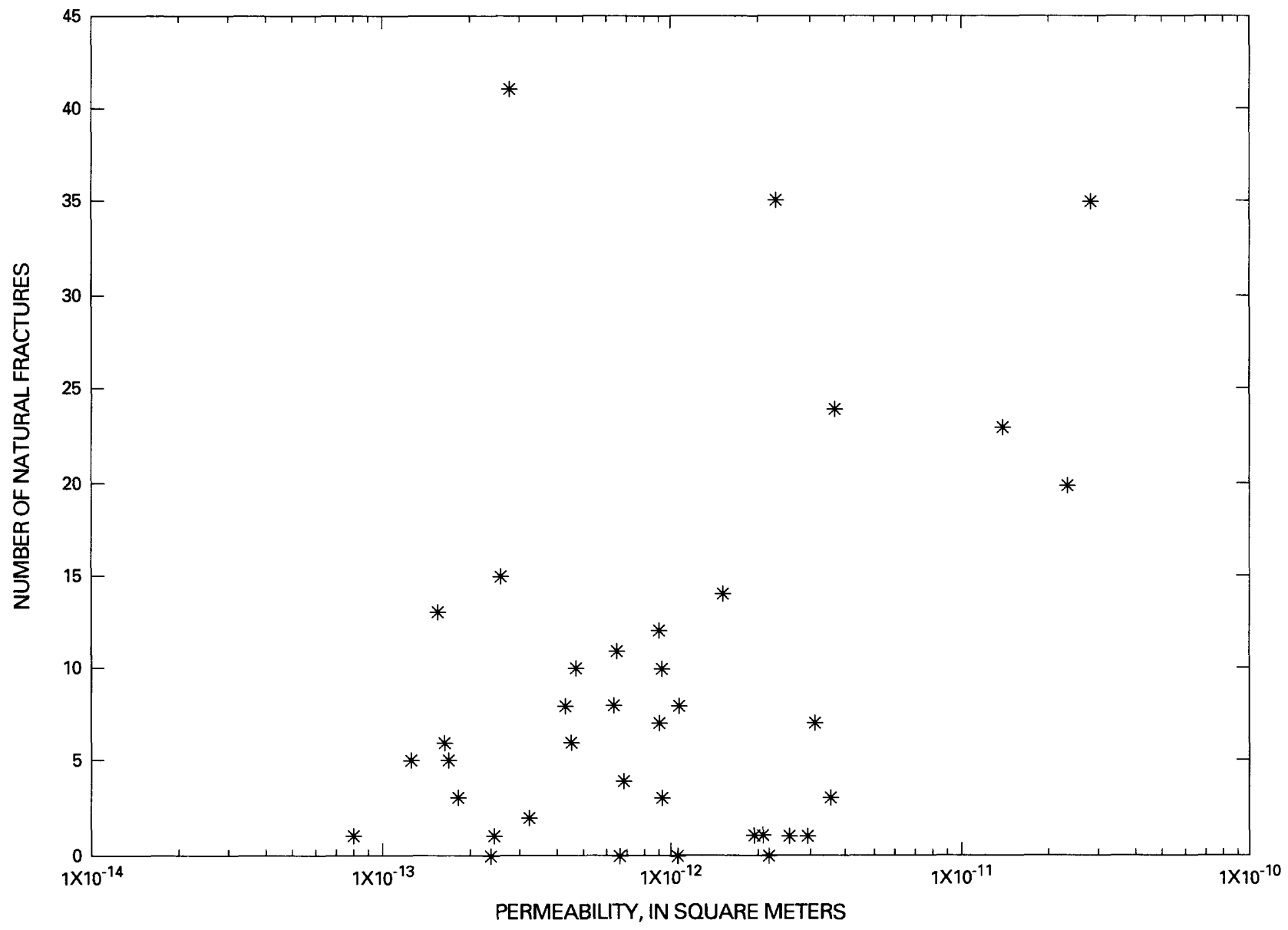

Figure 20. Relation of air-injection permeability values and number of natural fractures, borehole NRG-6.

\section{COMPARISON OF AIR-INJECTION PERMEABILITY VALUES TO LABORATORY PERMEABILITY VALUES}

Anderson (1994) did laboratory waterpermeability tests on core sample of welded tuffs of the Tiva Canyon and Topopah Spring Tuffs from boreholes USW GU-3/G-3 and USW G-4. The waterpermeability values ranged from less than $10^{-21} \mathrm{~m}^{2}$ to $1.5 \times 10^{-14} \mathrm{~m}^{2}$ with an average of approximately $10^{-18} \mathrm{~m}^{2}$. The water-permeability value of a single nonwelded core sample from the Paintbrush Group ranged from $6.0 \times 10^{-14} \mathrm{~m}^{2}$ to $1.5 \times 10^{-13} \mathrm{~m}^{2}$. These values are in agreement with water-permeability tests (Peters, 1984) on core samples from the same boreholes. Anderson (1991) also did laboratory waterpermeability tests on core samples from boreholes UE-25a \#4, \#5, \#6, and \#7. The welded Topopah Spring Tuff water-permeability values ranged from less than $10^{-18} \mathrm{~m}^{2}$ to $3.9 \times 10^{-14} \mathrm{~m}^{2}$ with an average of approximately $2.0 \times 10^{-15} \mathrm{~m}^{2}$. The samples analyzed by Anderson (1991) were mostly from the Topopah Spring crystal-rich nonlithophysal zone, which is a zone of increased porosity (Buesch and others, 1996) and, therefore, apparently increased matrix permeability. The water-permeability values (Anderson, 1991) of the nonwelded tuff of the Paintbrush Group included two Yucca Mountain Tuff samples, $4.2 \times$ $10^{-12} \mathrm{~m}^{2}$ and $2.5 \times 10^{-12} \mathrm{~m}^{2}$, and a single Pah Canyon Tuff sample, $2.0 \times 10^{-13} \mathrm{~m}^{2}$. Flint and Flint (1990) did laboratory air-permeability tests on core samples of the Paintbrush nonwelded tuff from several Yucca Mountain boreholes. Air-permeability values of the Pah Canyon Tuff ranged from $2.3 \times 10^{-15} \mathrm{~m}^{2}$ to $1.1 \times$ $10^{-13} \mathrm{~m}^{2}$; Yucca Mountain Tuff values ranged from $5.2 \times 10^{-15}$ to $3.2 \times 10^{-13} \mathrm{~m}^{2}$; and bedded units ranged from $1.0 \times 10^{-16} \mathrm{~m}^{2}$ to $3.6 \times 10^{-13} \mathrm{~m}^{2}$. The average 


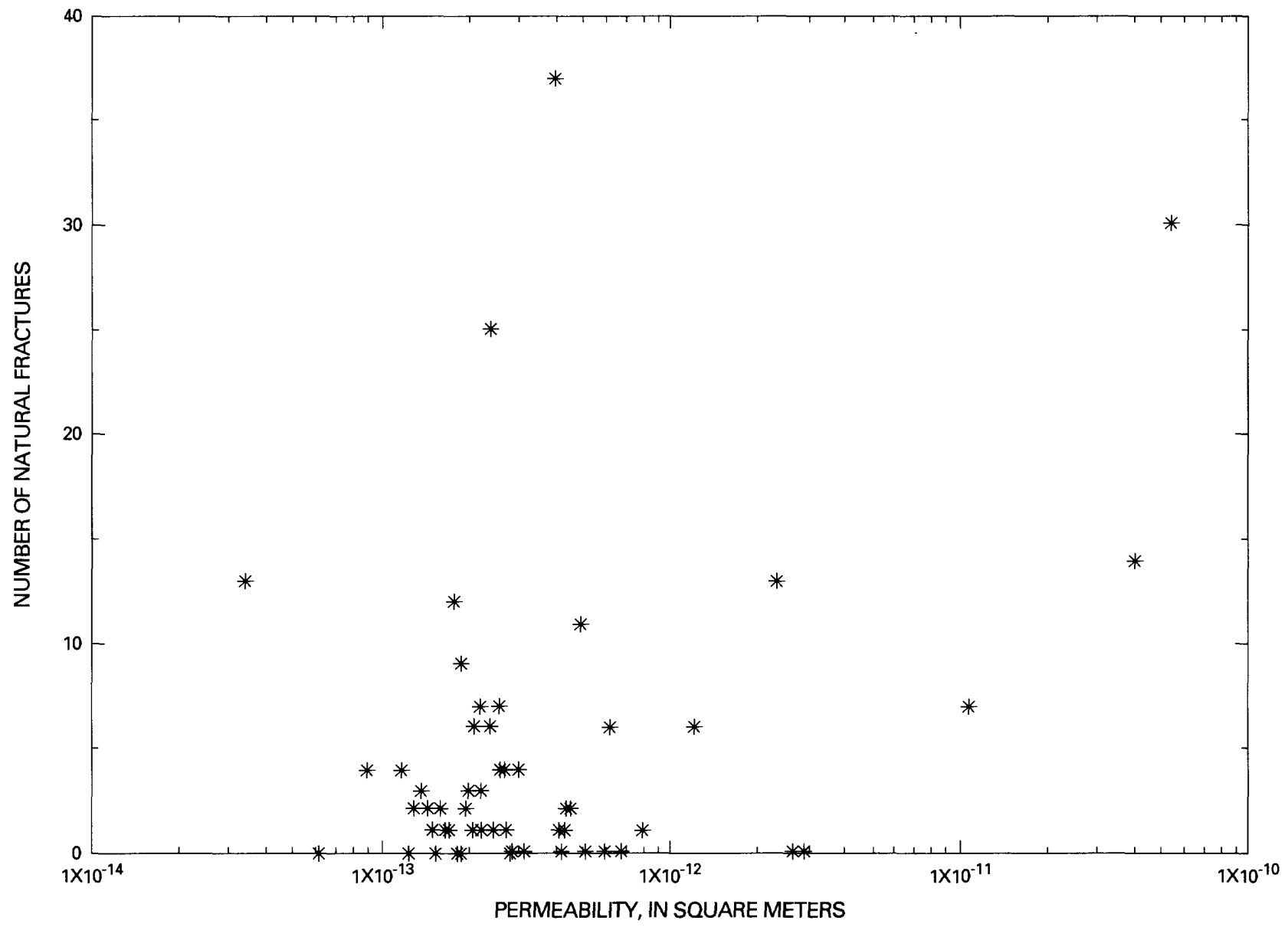

Flgure 21. Relation of air-injection permeability values and number of natural fractures, borehole NRG-7a.

air-permeability value for the Paintbrush nonwelded tuff was $1.3 \times 10^{-13} \mathrm{~m}^{2}$.

The air-injection permeability values of the Tiva Canyon and Topopah Spring Tuffs are 3 to 6 orders of magnitude greater than the Anderson (1991 and 1994) laboratory water-permeability values. The difference in permeability values indicates that the air-injection permeability values are dominated by fracture flow, whereas the Anderson values represent matrix flow.

The air-injection permeability values of the nonwelded tuff of the Paintbrush Group are as much as an order of magnitude greater than the Anderson (1994) and Flint (1990) laboratory water and airpermeability values. On the other hand, the airinjection permeability values of the Yucca Mountain Tuff are an order of magnitude smaller than the Anderson (1991) water-permeability values. These comparisons indicate that the nonwelded tuff is heterogeneous at the scale of the laboratory tests.

Most of the Paintbrush nonwelded tuff laboratory permeability values were too small to account for the higher permeability values derived from airinjection tests. Anderson (1991) reported two high Paintbrush nonwelded tuff water-permeability values that indicate that there may be some high-permeability sections in the Paintbrush nonwelded tuff but that these sections are not vertically continuous. The airinjection permeability values indicate fracture flow in the Paintbrush nonwelded tuff. The air-injection permeability values and fracture data from borehole NRG-7a indicate that vertical flow through the Paintbrush nonwelded tuff could be through fractures in the Yucca Mountain and Pah Canyon Tuffs and through the matrix in the bedded units. 


\section{COMPARISON OF AIR-INJECTION PERMEABILITY VALUES TO PNEUMATIC-MONITORING PERMEABILITY VALUES}

Table 9 presents the pneumatic-monitoring permeability values from boreholes NRG-6 and NRG-7a (E. Kwicklis, U.S. Geological Survey, written commun., 1996) and the air-injection permeability value arithmetic means and ranges.

The pneumatic-monitoring permeability values were derived from air-pressure data measured in isolated monitoring stations located at depths of 40 to $200 \mathrm{~m}$ below ground surface in boreholes NRG-6 and NRG-7a. The pressure responses measured in the pneumatic-monitoring intervals are caused by atmospheric pressure changes. The pressure-response dampening and time lag is used to estimate the pneumatic diffusivity of the rock between the ground surface and the monitoring station. Because the pressure response in the monitor interval was transmitted through 40 to $200 \mathrm{~m}$ of rock, the zone of investigation is 40 to $200 \mathrm{~m}$.

The pneumatic-monitoring permeability value from borehole NRG-6 of the Tiva Canyon Tuff is in the range of the air-injection permeability values. Of the four Tiva Canyon Tuff air-injection permeability values, two are larger and two smaller than the pneumatic-monitoring permeability value. The pneumatic-monitoring permeability values from borehole NRG-6 of the nonwelded tuff of the Paintbrush Group are in the range of the NRG-7a airinjection permeability values. The Topopah Spring Tuff pneumatic-monitoring permeability values from boreholes NRG-6 and NRG-7a are approximately an order of magnitude larger than the air-injection permeability values.

Comparison of the pneumatic-monitoring and air-injection permeability values shows the effect of scale on test results. The Tiva Canyon Tuff and Paintbrush nonwelded tuff pneumatic-monitoring permeability values fall in the range of the airinjection permeability values. This is expected because at the scale of the air-injection tests (an ellipsoid with a zone of influence of approximately $4 \mathrm{~m}$ ), the Tiva Canyon and Paintbrush nonwelded tuff are heterogeneous. At the scale of the pneumaticmonitoring ( 40 to $200 \mathrm{~m}$ vertically), the heterogeneity is lost in an average permeability value.

The Topopah Spring Tuff pneumatic-monitoring permeability values are an order of magnitude larger than the air-injection permeability values. One possible explanation is that the permeability of the Topopah Spring Tuff is anisotropic. A vertical borehole that penetrates a geologic formation dominated by vertical fractures may intersect few fractures and, therefore, may not provide a representative sample for in-situ air-injection tests. The airinjectic.. wo intervals may have poor pneumatic connections to the vertical fracture system. The testinterval permeability value will be dominated by the poor connection, not by the vertical fracture permeability. The air-injection permeability values may be better estimates of horizontal than vertical permeability.

During pneumatic monitoring, the pressure response and time lag are controlled by transmission through the vertical fractures. If a pneumatic-monitor interval has a poor pneumatic connection to the vertical fracture system, the pneumatic-monitor

Table 9. Pneumatic-monitoring permeability values and air-injection permeability values from boreholes NRG-6 and NRG-7a by geologic unit

\begin{tabular}{lcccc} 
[Units are $\times 10^{-12}$ square meter; - is no data] & $\begin{array}{c}\text { NRG-6 } \\
\text { pneumatic } \\
\text { monitoring }\end{array}$ & $\begin{array}{c}\text { NRG-6 air injection } \\
\text { arithmetic mean } \\
\text { (range) }\end{array}$ & $\begin{array}{c}\text { NRG-7a } \\
\text { pneumatic } \\
\text { monitoring }\end{array}$ & $\begin{array}{c}\text { NRG-7a air injection } \\
\text { arithmetic mean } \\
\text { (range) }\end{array}$ \\
\hline Tiva Canyon Tuff & 3.1 & $\begin{array}{c}11.2 \\
(0.3-28.0)\end{array}$ & -- & $\begin{array}{c}17.8 \\
(0.1-54.0)\end{array}$ \\
Paintbrush nonwelded tuff & $0.5-2.0$ & -- & - & 0.6 \\
& & & & $(0.1-3.0)$ \\
Topopah Spring Tuff & $10.0-50.0$ & 2.1 & 10.0 & 0.4 \\
& & $(0.08-24.0)$ & & $(0.04-2.4)$
\end{tabular}


interval pressure response is still dominated by the vertical fracture system. Based on the assumption that the air-injection permeability values represent the horizontal permeability and the pneumatic-monitoring permeability values represent the vertical permeability, the vertical to horizontal anisotropy ratio is approximately 10:1.

Like the Topopah Spring Tuff, the Tiva Canyon Tuff is dominated by vertical fractures, yet test results do not indicate anisotropy. A possible explanation is that the Tiva Canyon Tuff has increased horizontal permeability. An increase in the horizontal permeability is supported by the higher Tiva Canyon Tuff fracture density, identified in boreholes NRG-6 and NRG-7a, and the higher Tiva Canyon Tuff airinjection permeability values, identified in all four boreholes. The increase in horizontal permeability could be due to the decreased overburden and associated stress relief alteration of the horizontal flow paths. Increased horizontal permeability reduces the potential of poor horizontal pneumatic connections attributed to the Topopah Spring Tuff anisotropy.

When the air-injection permeability values and the pneumatic-monitoring permeability values are compared, it is important to understand the use of the diffusivity term. The pneumatic-monitoring permeability values are derived from the pneumaticdiffusivity model (Weeks, 1978). The diffusivity model uses a pneumatic-diffusivity term with permeability in the numerator and porosity in the denominator; therefore, the permeability value and the porosity can change while the pneumatic-diffusivity term remains constant. The pneumatic-monitoring permeability values presented here assume an effective air-filled porosity of the Topopah Spring Tuff of 5 percent. Based on this porosity, the permeability of the Topopah Spring Tuff is estimated at $10 \times$ $10^{-12} \mathrm{~m}^{2}$ to $50 \times 10^{-12} \mathrm{~m}^{2}$. A 5-percent effective porosity is a good estimate, but the actual value is unknown. If the effective porosity is actually one-half the estimated value ( 2.5 percent), the permeability values also will be half.

\section{SUMMARY AND CONCLUSIONS}

Air-injection tests with straddle packers were conducted in four vertical boreholes (UZ-16, SD-12, NRG-6, and NRG-7a) at Yucca Mountain, Nevada. Pneumatic pressure responses were monitored in the test and guard intervals during constant flow-rate air-injection tests. Air-injection permeability values were calculated based on the test-interval steady-state pressures and the air-injection rates. Tests were conducted at different flow rates to evaluate turbulence and inertial effects. To minimize turbulence and inertial effects, flow rates were selected that limited most of the steady-state differential pressures to less than $30 \mathrm{kPa}$. Of the 181 test intervals tested at multiple flow rates, 170 had minimum airinjection permeability values that were within 30 percent of their maximum air-injection permeability values. Temperature changes in the test intervals were less than $2.5^{\circ} \mathrm{C}$. Temperature changes in the guard intervals were less than $0.2^{\circ} \mathrm{C}$.

Air-injection permeability values of the Tiva Canyon Tuff ranged from $0.3 \times 10^{-12} \mathrm{~m}^{2}$ in the crystalpoor lower nonlithophysal zone in borehole NRG-6, to $54.0 \times 10^{-12} \mathrm{~m}^{2}$ in the same zone in borehole NRG-7a. The shallow test intervals in the Tiva Canyon Tuff had the highest air-injection permeability values. Airinjection permeability values of the Paintbrush nonwelded tuff ranged from $0.12 \times 10^{-12} \mathrm{~m}^{2}$ in the Pah Canyon Tuff to $3.0 \times 10^{-12} \mathrm{~m}^{2}$ in the bedded tuff number 3. Air-injection permeability values of the Topopah Spring Tuff ranged from $0.02 \times 10^{-12} \mathrm{~m}^{2}$ in the crystal-poor middle nonlithophysal zone in borehole UZ-16 to $33.0 \times 10^{-12} \mathrm{~m}^{2}$ in the crystal-rich lithophysal zone in borehole SD-12.

The variograms of boreholes UZ-16, NRG-6, and SD-12 show a hole effect. The hole effect is due to the decrease in permeability with depth identified in several geologic zones. This indicates some structural control of the permeability distribution, possibly associated with the deposition and cooling of the tuff.

The Topopah Spring Tuff air-injection permeability values from borehole NRG-7a are smaller and have a smaller range than those from boreholes UZ-16, SD-12, and NRG-6. Analysis of variance between means indicates that borehole NRG-7a has a different mean-permeability value. Variograms of boreholes UZ-16, NRG-6, and SD-12 have similar variogram values and show a hole effect. Borehole NRG-7a has smaller variogram values and no hole effect. The data indicates that there is areal variation in the permeability values of the Topopah Spring Tuff.

Air-injection redistribution of water was limited to deep tests on the Calico Hills Formation in borehole UZ-16 and three shallow Tiva Canyon Tuff test 
intervals in borehole SD-12. The Calico Hills

Formation test interval was located at $395.3-399.3 \mathrm{~m}$ below ground surface and $91.5 \mathrm{~m}$ above the water table. The pre-test capillary pressure of the test interval was less than $43.3 \mathrm{kPa}$. In a system at static equilibrium, the capillary pressure of the test interval should be approximately $870.0 \mathrm{kPa}$, which indicates that there must be a source of moisture other than the water table. The borehole SD-12 Tiva Canyon Tuff test intervals were located at $39.6,42.4$, and $77.1 \mathrm{~m}$ below ground surface. The tests indicate that water flowed in the fractures after a wet winter.

The fracture densities of the Tiva Canyon and Topopah Spring Tuffs are the same in boreholes UZ-16 and SD-12. The fracture density of the Tiva Canyon Tuff is approximately four times larger than the Topopah Spring Tuff in boreholes NRG-6 and NRG-7a. One possible explanation is location. Although no geographic reason has been identified, boreholes NRG-6 and NRG-7a are both located on the edge of Drill Hole Wash in the northern end of the repository area. Boreholes UZ-16 and SD-12 are located in the southern half of the repository. The Agapito and Associates geology and rock structure logs of boreholes NRG-6 and NRG-7a indicate that few fractures have infilling and the few that have infilling are limited to shallow depths. The absence of infillings indicates that most of the fractures are open to air and water flow.

Regression analysis between air-injection permeability values and six independent variables (total fractures, natural fractures, indeterminate fractures, and percentage of lithophysal cavities, core rubble, and core lost) indicates some correlation between the number of natural fractures and permeability for boreholes NRG-6 and NRG-7a. Boreholes UZ-16 and SD-12 had no correlations.

The air-injection permeability values of the Tiva Canyon and Topopah Spring welded tuffs are three to six orders of magnitude greater than their matrix permeability values. The higher air-injection permeability values are due to fracture flow.

The air-injection permeability values of the Paintbrush nonwelded tuffs are generally higher than their matrix permeability values. Most of the Paintbrush nonwelded tuff laboratory matrix permeability values are too small to account for the higher permeability values derived from air-injection tests. Anderson reported two high Paintbrush nonwelded tuff matrix permeability values, which indicate that there may be some high-permeability sections in the Paintbrush nonwelded tuff, but they are not vertically continuous. The data indicate that there are open fractures in the Paintbrush nonwelded tuff.

The Tiva Canyon Tuff pneumatic-monitoring permeability value agrees with the air-injection permeability values. The Paintbrush nonwelded tuff pneumatic-monitoring permeability value agrees with the air-injection permeability values. The Topopah Spring Tuff pneumatic-monitoring permeability values are an order of magnitude larger than the airinjection permeability values. Comparison of the two test methods indicates that the Topopah Spring Tuff is anisotropic with a vertical to horizontal permeability ratio of 10:1.

\section{REFERENCES CITED}

Anderson, L.A., 1991, Results of rock property measurements made on core samples from Yucca Mountain boreholes, Nevada Test Site, Nevada: U.S. Geological Survey Open-File Report 90-474, 43 p.

Anderson, L.A., 1994, Water permeability and related rock properties measured on core samples from the Yucca Mountain USW GU-3/G-3 and USW G-4 boreholes, Nevada Test Site, Nevada: U.S. Geological Survey Open-File Report 92-201, 36 p.

Bikerman, J.J., 1958, Surface chemistry theory and applications: New York, Academic Press, Inc., 501 p.

Buesch, D.C., Spengler, R.W., Moyer, T.C., and Geslin, J.K., 1996, Proposed stratigraphic nomenclature and macroscopic identification of lithostratigraphic units of the Paintbrush Group exposed at Yucca Mountain, Nevada: U.S. Geological Survey Open-File Report 94-469, $45 \mathrm{p}$.

Dullien, F.A.L., 1992, Porous media, in Fluid transport and pore structure ( $2 \mathrm{~d}$ ed.): San Diego, Academic Press, Inc., $574 \mathrm{p}$.

Flint, L.E., and Flint, A.L., 1990, Preliminary permeability and water-retention data for nonwelded and bedded tuff samples, Yucca Mountain Area, Nye County, Nevada: U.S. Geological Survey Open-File Report 90-569, $57 \mathrm{p}$.

Geslin, J.K., Moyer, T.C., and Buesch, D.C., 1995, Summary of lithologic logging of new and existing boreholes at Yucca Mountain, Nevada, August 1993 to February 1994: U.S. Geological Survey Open-File Report 94-342, 39 p.

Hvorslev, M.J., 1951, Time lag and soil permeability in ground-water observations: Vicksburg, Miss., U.S. Army Corps of Engineers Bulletin 36, 47 p. 
Kearl, P.M., Zinkl, R.J., Dexter, J.J., and Cronk, T., 1990, Air permeability measurements of the unsaturated Bandelier Tuff near Los Alamos, New Mexico: Journal of Hydrology, v. 117, p. 225-240.

Klinkenberg, L.J., 1941, The permeability of porous media to liquids and gases: New York, Drilling and Production Practice, American Petroleum Institute, p. 200-213.

LeCain, G.D., and Walker, J.N., 1994, Results of airpermeability testing in a vertical borehole at Yucca Mountain, Nevada: Proceedings of the Fifth Annual International Conference on High-Level Radioactive Waste Management, May 22-26, Las Vegas, Nev., p. 2782-2788.

LeCain, G.D., 1995, Pneumatic testing in 45-degreeinclined boreholes in ash-flow tuff near Superior, Arizona: U.S. Geological Survey Water-Resources Investigations Report 95-4073, 27 p.
Moyer, T.C., and Geslin, J.K., 1995, Summary of lithologic logging of new and existing boreholes at Yucca Mountain, Nevada, July 1994 to November 1994: U.S. Geological Survey Open-File Report 95-102, 7 p.

Noggle, J.H., 1985, Physical chemistry: Boston, Little, Brown and Company, p. 452.

Norman, R., and Archer, J.S., 1988, High-velocity gas flow in liquid-saturated porous media and its visualization, Journal of Canadian Petroleum Technology: v. 27, no. 3, p. 64-69.

Peters, R.R., Klavetter, E.A., Hall, I.J., Blair, S.C., Heller, P.R., and Gee, G.W., 1984, Fracture and matrix hydrologic characteristics of tuffaceous materials from Yucca Mountain, Nye County, Nevada: Sandia Report SAND84-1471, $188 \mathrm{p}$.

Weast, R.C., ed., 1987, CRC handbook of chemistry and physics: Boca Raton, Fla., CRC Press, Inc.

Weeks, E.P., 1978, Field determination of vertical permeability to air in the unsaturated zone: U.S. Geological Survey Professional Paper 1051, 31 p. 